\title{
Türk İşaret Dili İncelemesi: İletişim ve Dil Bilgisi
}

\section{Turkish Sign Language Analysis: Communication and Grammar}

\author{
Mehmet Fatih Karaca \\ Tokat Gaziosmanpaşa Üniversitesi \\ mfkaraca@gmail.com \\ Şafak Bayır \\ Karabük Üniversitesi \\ safakbayir@karabuk.edu.tr
}

\begin{abstract}
Alıntılama: Karaca, M. F. \& Bayır, Ş. (2018). Türk İşaret Dili İncelemesi: İletişim ve Dil Bilgisi. Ulusal Eğitim Akademisi Dergisi (UEAD), 2(2), 35-58.

Geliş tarihi:

28 Ağustos 2018

Kabul tarihi:

24 Eylül 2018

Sorumlu yazar:

Mehmet Fatih Karaca

mfkaraca@gmail.com

(C) 2018 UEAD.

Bütün hakları saklıdır.

Özet: İletişim kaynak ile hedef arasında mesaj aktarımı, bir kişiden diğer kişi/kişilere bilgi iletimi, duygu, düşünce ve fikir gibi her türlü anlam alışverişi şeklinde tanımlanabilir. İnsanlar arasında en çok, temeli duyma ve konuşma olan sözlü iletişim kullanılmaktadır. Fakat işitme kaybından kaynaklı olarak işitme engellilerin bu iletişim yöntemini ya kullanamadıkları ya da sınırlı kullanabildikleri görülmektedir. İşitme engelli bireyler iletişim ihtiyaçlarını karşılamak üzere sözlü iletişimden farklı olarak işaret dili, yazma yöntemi ve dudak okuma gibi tekniklere başvururlar. Kendi aralarında çoğunlukla işaret, parmak alfabesi, jest ve mimiklerden oluşan işaret dilini kullanırlar. İşiten bireylerle yazarak iletişim kursalar da bu yöntemin yavaş olması fazla tercih edilmemesine neden olmaktadır.

Bu çalışmada, Türk İşaret Dili (TİD)'nde kullanılan iletişim yöntemleri ve TíD dil bilgisi konuları ele alınmıştır. İletişimde kullanılan yöntemler olarak işaretler, parmak alfabesi, ağızla söyleme ve jest mimik konuları incelenmiştir. Dil bilgisi olarak ise işaret türetme, eş işaretli işaretler, eş anlamlı ve zıt anlamlı işaretler, birleşik işaretler, TíD'de kullanılan ekler ve söz dizimi ele alınmış ve bunlara ilişkin örneklerin üç boyutlu model üzerinden gösterimi yapılmıştır.
\end{abstract}

Anahtar kelimeler: Türk Işsaret Dili, işaret dili, iletişim, işaret, dil bilgisi.

Received:

28 August 2018

Accepted:

24 September 2018

Corresponding author: Mehmet Fatih Karaca mfkaraca@gmail.com

(C) 2018 UEAD. All rights reserved.
Abstract: Communication can be defined as conveying a message between source and target, transferring information from an individual to other people, and exchanging all types of meaning such as emotion, opinion and idea. Verbal communication based on hearing and speaking is predominantly used among people. However, it is seen that the hearing-impaired individuals either cannot use this communication system or can use it in a limited way as a result of having hearing loss. Hearing-impaired individuals use the techniques such as sign language, writing method and lip-reading which are different from verbal communication in order to meet their communication needs. They mostly use sign language consists of signs, finger alphabet, gestures and facial expressions among themselves. They establish communication with hearing people by writing, this method is not generally preferred since it is slow.

In this study, the topics of "the communication methods used in Turkish Sign Language (TSL)" and "TSL grammar" are taken into consideration. The topics of signs, finger alphabet, saying with mouth movements, gestures and facial expressions were examined as the methods used in communication. The topics of sign derivation, signs consist of counterpart signs, synonym and antonym signs, compound signs, affixes used in TSL 
and syntax were examined as grammatical issues and examples related to these were demonstrated on 3D model.

Keywords: Turkish Sign Language, sign language, communication, sign, grammar.

\section{Giriş}

İletişim; kaynak ile hedef arasında mesaj aktarımı; bir kişiden diğer kişi/kişilere bilgi iletimi; duygu, düşünce ve fikir gibi her türlü anlam alışverişi şeklinde tanımlanabilir. Genel anlamda iletişim, insanların duygu, düşünce, inanç, tutum ve davranışlarının sözlü, sözsüz, yazılı veya elektronik olarak karşıya aktarımıdır. Sözlü ve sözsüz iletişim iki temel iletişim yöntemidir (Tutar vd., 2014). İnsanlar arasında en yaygın kullanılan iletişim türü, temeli duyma ve konuşma olan sözlü iletişimdir. Fakat işitme kaybından kaynaklı olarak işitme engellilerin bu iletişim yöntemini ya kullanamadıkları ya da sınırlı olarak kullanabildikleri görülmektedir. İşitme engelli bireyler iletişim ihtiyacını karşılamak üzere sözlü iletişimden farklı olarak işaret dili, yazma yöntemi ve dudak okuma tekniklerine başvururlar.

İşaret dili, işitme engellilerin kendi aralarında yaygın olarak kullandıkları en temel iletişim tekniğidir; el hareketleri, jest, mimikler, tamamlayıcı veya pekiştirici özellik olan ağızla söylemeden oluşur. İşaret dilleri sözsüz iletişim unsurlarını barındıran bir dildir. Sözsüz iletişimde jestler ve hareketler gibi birtakım simgelerle iletişim kurulur (Tutar vd., 2014).

İşitme engellilerin kendi aralarında iletişimlerini işaret diliyle sağladıkları görülse de işitenlerle iletişim ortak bir iletişim aracı olmadığından sınırlı kalmaktadır. İşitme engellilerin işitmeyi ve dolayısıyla konuşmayı gerçekleştirmeleri çok zor veya imkânsız olacağına göre; işitenlerle işitme engellilerin iletişiminde kullanılacak en doğru yol işitenlerin işaret dili öğrenmeleridir.

İşitme engellilerin Türkçe kullanımları incelendiğinde yazımda yer alan bazı unsurlara dikkat etmedikleri tespit edilmiş̧ir. Örneğin noktalama işaretlerini kullanmadıkları, kullanmakta zorlandıkları ve cümle yazımında ilk harfleri büyük yazmadıkları görülmektedir. Bunun yanında Akçamete (1999) işitme kaybı olan çocuklarla ilgili olarak şu tespitlerde bulunmuştur;

- Sinırlı sözcükler kullanırlar.

- Çoğul ve bazı diğer ekleri, edat ve fiilleri ihmal ederler.

- Kisa ve basit cümleler kurarlar.

- Soru cümlelerini anlama ve cevap vermede zorlanırlar.

Bu çalışmada, TỉD'de kullanılan iletişim yöntemleri ve TiD dil bilgisi konuları ele alınmıştır. İletişimde kullanılan yöntemler olarak işaretler, parmak alfabesi, ağızla söyleme ve jest mimik konuları incelenmiştir. Dil bilgisi olarak ise işaret türetme yöntemleri, eş işaretli, eş anlamlı, zıt anlamlı ve birleşik işaretler ile TiD'de kullanılan ekler ve söz dizimi ele alınmıştır.

\section{2. İşaret Dili}

İşitme engellilerin konuşma dillerindeki hâkimiyetleri işitme kaybının derecesine bağlı olarak değiş̧kenlik gösterebilir. İşitme engelliler, kendilerini ifade etmek için ana dilleri olan işaret dillerini yoğun olarak kullanırlar. İşaret dili, doğal bir dil olup kendine has dil bilgisi, parmak alfabesi ve işaretleri bulunan; el, yüz ve mimiklerden oluşan; işitme engellilerin kendi aralarında ve işiten bireylerle iletişim kurmak için kullandıkları en temel görsel iletişim yöntemidir. 
Her ülkenin işaret dili farklıdır. İşitme engellilerin farklı işaret dilleriyle iletişim kurmaları farklı iki ülke vatandaşlarının farklı diller kullanarak konuşmaları kadar doğaldır. Her ülke işaret dilinin kendine has kuralları vardır. Bazı yanlış bilgiler bulunmakla birlikte işaret dilleriyle ilgili şunlar söylenebilir;

- Konuşma dillerinde olduğu gibi kendine has dil bilgisi kuralları vardır.

- Konuşma dillerinden etkilenmiş olmaları konuşma dillerinden türediğini göstermez.

- Konuşma dillerinde olduğu gibi erken yaşlarda öğrenilmesi gerekir.

- Konuşma dilleri ile işaret dilleri aynı sinir fizyolojisi ve yerleşimdedir.

- Her ülkenin işaret dili ve dil bilgisel kuralları farklıdır.

- Bir ülkedeki farklı bölgelerde bazı işaretlerde küçük değişimler görülebilir.

- İşaretlerin gösteriminde tek veya çift el kullanılabilir.

\section{Türk İşaret Dili}

TiD, dünyadaki en eski işaret dillerinden biri olarak kabul edilir (Zeshan, 2003). TiD'in varlığı ve tarihi ile sınırlı sayıda bilgi varken dil bilgisi ile ilgili bilgi neredeyse yok denecek kadar azdır. İşitme engellilerin konuşmalarını geciktirdiği düşüncesiyle 1953 yılında sağır dilsiz okullarında işaret dili yasaklanmıştır. Bunun sonucu olarak işaret dili sözlüğü, dil bilgisi ve ders kitaplarının hazırlanması, ulusal işaret dilinin oluşması/yaygınlaşması engellenmiş (Akalın, 2013) ve dolayısıyla TiD'le ilgili çalışmaların yapılması da gecikmiştir. Bu yasak neticesinde TíD'in okullarda kullanılamaması ve öğretilmemesiyle tek ve ortak işaretler üretilememiş, TíD bölgeden bölgeye farkl1lık gösteren bir dil haline gelmiştir. Fakat gelişmiş ülkelerde nispeten ulusal ortak bir işaret dili olduğu, en azından dil bilgisi kuralları ile ilgili daha fazla kaynağa erişebildiği görülmektedir.

TID ile ilgili temel niteliğinde olan akademik çalışma Alman araştırmacı Zeshan (2003) tarafından yapılmıştır. TiD'in konu edindiği makalelerde genellikle TiD işaretlerinin görüntü işleme teknikleriyle tanınması konusunun ele alındığı, TiD'in dil bilgisi özelliklerinin ise kısmen işlendiği görülmüştür.

\subsection{TİD İletişim Yöntemleri}

İletişimin sözlü, sözsüz, yazılı ve elektronik olmak üzere 4 türü (Tutar vd., 2014) olmasına karşın işitme engelliler sözsüz, yazılı ve elektronik iletişim yöntemlerini tercih etmektedirler. Ayrıca, işitme engellilerin ana dili TỉD olan/olmayan ve işaret dili bilmeyen bireylerle iletişimi farklılık göstermektedir. Ana dili TỉD olan bireylerle iletişimde genellikle sözsüz iletişim olan işaret dilini kullanırlar. TíD'i sonradan öğrenen işitme engelli ve işiten bireylerle iletişimde işaret dilini tercih ettikleri, parmak alfabesi ve ağızla söylemenin kullanımının arttığı görülmektedir. Türkçe konuşan ve işaret dili bilmeyen kişilerle iletişimde ise dudak okuma ve ağızla söylemeyle iletişim kurmaya çalışmaktadırlar (Dikyuva vd., 2015). Ayrıca, okuma-yazma bilen işitme engelliler işiten bireylerle yazma yöntemini kullanarak da iletişim kurabilmektedirler.

Konuşma dilleriyle gerçekleştirilen iletişimde işitsel-sessel, işaret dillerinde ise görseluzamsal kanal kullanılmaktadır (Özkul, 2016). Beynimizde ilk gelişen zekâ olan görsel-uzamsal zekâ ile görülen nesnelerin yer ve yön kavramını da içine alacak şekilde nesnelerin diğer nesnelere veya yere göre konumları dikkate alınmaktadır. İşitsel-sessel kanal ile sağlanan 
iletişimin aksine görsel-uzamsal kanal ile sağlanan iletişimde de kişilerin birbirlerini görmesi gerekir.

İşaret dilleri iletişimde güçlü dillerdir. Birden fazla ifadenin aynı anda verilmesi anlamına gelen eş zamanlılık, işaret dillerinde konuşma dillerine oranla daha yoğun şekilde görülmektedir (Özkul, 2016). Konuşma dilleri kullanım şekli itibariyle eş zamanlılığa nispeten imkân sağlamaktadır. O geldi mi? soru cümlesi konuşma dilinde herhangi bir eş zamanlı ifade gerektirmezken işaret dilinde kaş ve baş hareketlerinin eş zamanlı olarak ifadede yer alması gerekir. Ayrıca, işaret dillerinde işarete eş zamanlı olarak yüz veya vücut ifadelerinin eklenmesiyle anlam tamamen değişebilmektedir (Şekil 1).

Şekillerdeki gösterimlerde $\sim$ tekrar eden işareti, $\wedge$ işaret birleşimli işareti, + ek birleşimlerini, [SPAR] soru parçacığını, $\uparrow_{\_} \bullet$ el dışı işaretin başlangıcını, $\downarrow$ _ bitişini, di bitmişlik görünüşünü, yor sürerlik görünüşünü, bö baş önde el dışı işaretini, by baş yukarıda el dışı işaretini, ky kaş yükseltme el dışı işaretini, ki kaş indirme el dışı işaretini ifade etmektedir.
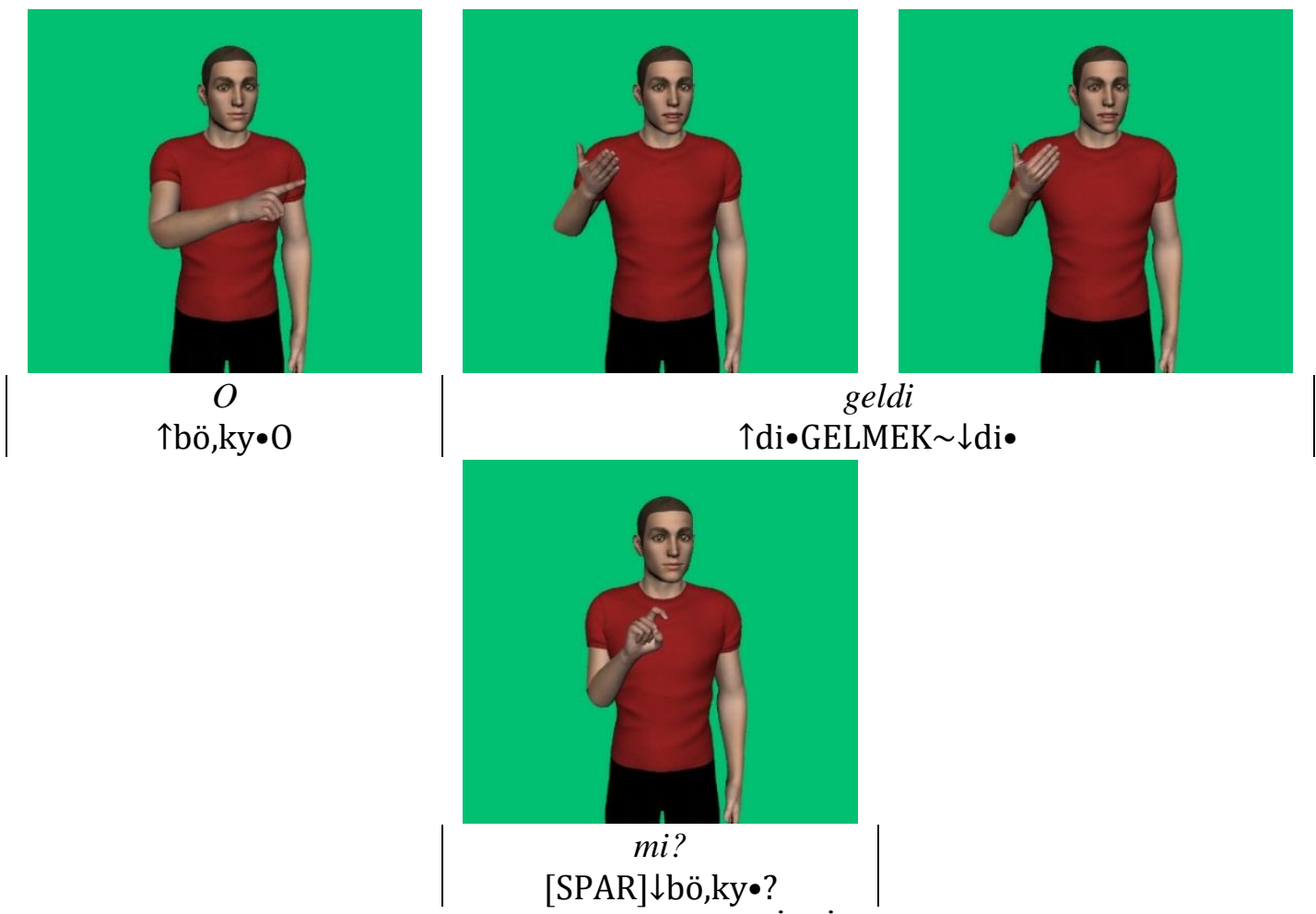

Şekil 1. "O geldi mi? ” Cümlesi TID İşaret Gösterimi

\subsection{1. İşaretler}

İşaretler durağan ve durağan olmayan işaretler olmak üzere ikiye ayrılır. Durağan işaretler, işaret yapılırken elin durumunda değişik olmayan, durağan olmayan işaretler ise işaretin başlangıç ve bitiş anlarında elin durumunun farklı olduğu işaretler için kullanılır. Durağan işaretler tek bir imge (Şekil 2) ile ifade edilebilirken durağan olmayan işaretler sıralı imgeler (Şekil 3) şeklinde ifade edilebilir. 


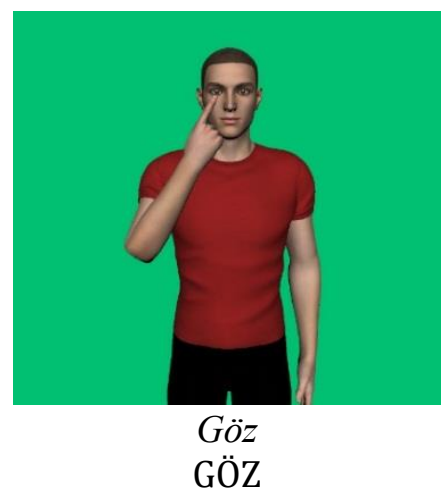

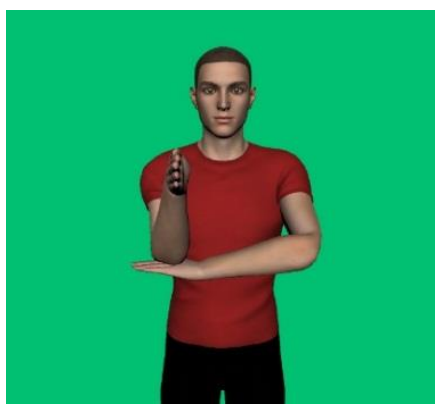

Durak DURAK

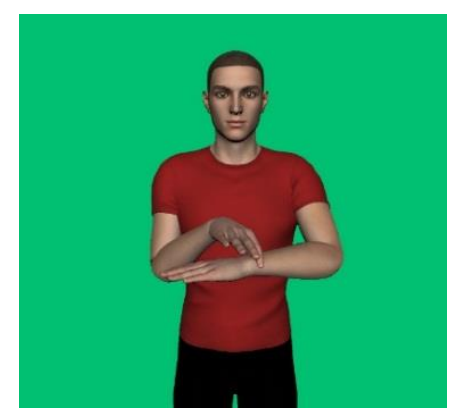

Hasta

HASTA

Şekil 2. Durağan İşaretler: "Göz”, "Durak", "Hasta”

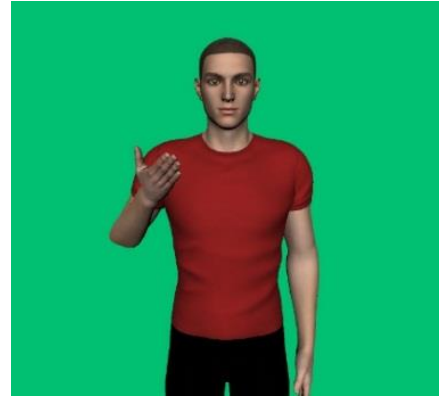$$
\mid
$$
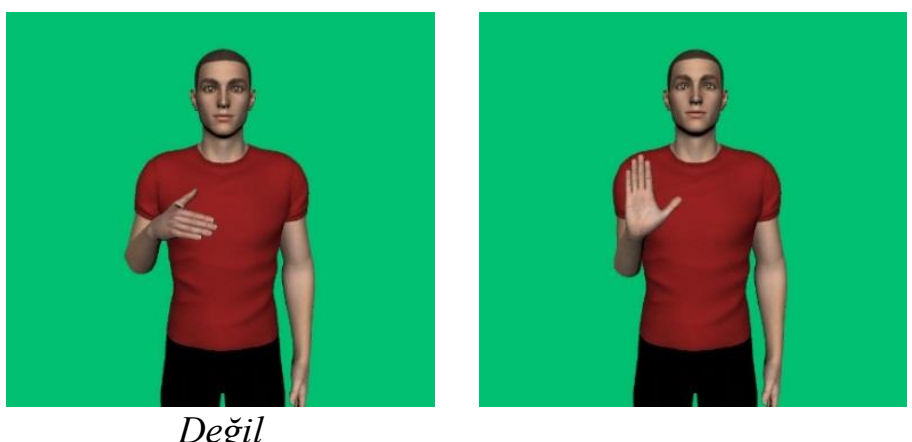

个by,ky•DEĞiL $\downarrow$ by,ky•

Şekil 3. Durağan Olmayan İsaret: "Değil"

İşaretler kelime tabanlıdır (Bayrak, 2009); yani kelime, onu karşılayan bir işaretle gösterilmektedir. Bazı işaretlerde kelime ile işareti arasında bağ kurulabilirken bazılarında kurulamayabilir. $\mathrm{Bu}$, işaretin anlamsız sembollerden oluştuğunu göstermez. Örneğin; OTOBÜS kelimesinin işareti anlamsız gibi durabilir. Fakat işaret incelendiğinde aslında işaretin ayaktaki yolcunun otobüste tutma yerini temsil ettiği görülmektedir (Şekil 4).

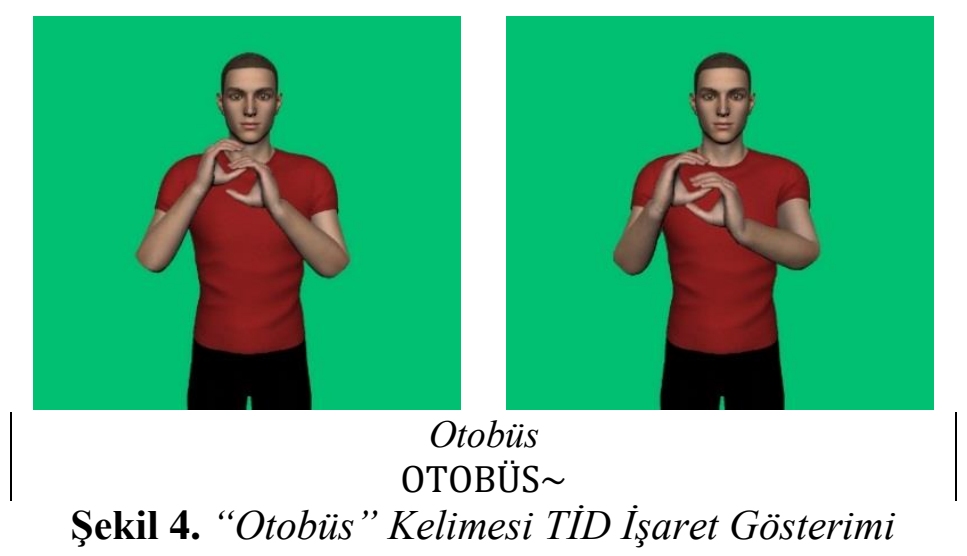

İşaret dillerinde işaretler şeffaf, yarı şeffaf ve şeffaf olmayan şekillerde bulunabilmektedir. Yapılan işaretin hangi kelimeye ait olduğunun doğrudan tahmin edilebildiği işaretlere şeffaf işaret, yapılan işaretin hangi kelimeye ait olduğunun doğrudan tahmin edilemediği ancak işaret ve kelimesi bilindikten sonra bağın kurulabildiği işaretlere yarı şeffaf işaret, yapılan işaretin hangi kelimeye ait olduğunun tahmin edilemediği ve kelime ile işareti 
arasında hiçbir bağın kurulamadığı işaretlere ise şeffaf olmayan işaret denir (Klima \& Bellugi, 1979). Her kelime ile işareti arasında bağ kurulması gerekmez; yani işaret kelimeye mutlak benzemek durumunda değildir.

Kimi kelimeler tek işaretle kimi kelimelerde birkaç işaretin birleşimiyle ifade edilebilmektedir (Uysal, 2010), dahası bir işaret bir cümleyi de ifade edebilmektedir (Memiş, 2013). Bunun yanında işaret dillerinde bazı işaretler vardır ki uygulama yerine göre faklı anlamlar verirler (Türk, 2015). Örneğin; kalp üzerinde yapılan kötü işareti art niyetli, yüzde yapılan kötü işareti ise çirkin anlamına gelir.

Kelimelerin türlerine göre işaretleri incelendiğinde isim işaretlerinin fiil işaretlerine göre daha kısa sürede icra edildiği ve tekrarlamayla ilgili ayırt edici bir özellik bulunmadığı görülmüştür (Özkul, 2016). Elbette bu, bütün işaretlerin bu şekilde uygulandığını ortaya koymaz; işaretlerde daha yoğun olarak bu kullanımın görüldüğü söylenebilir.

\subsubsection{Parmak Alfabesi}

Parmak alfabesi el abecesi, alfabe veya işaret dili alfabesi şeklinde isimlendirilebilir. Doğal ve kendiliğinden olmamaları, insanlar tarafından üretilmiş olmaları gibi sebeplerden ötürü parmak alfabesi dil dışı olarak kabul edilmektedir (Taşçı, 2016). Konuşma dillerinde kelimeler harflerin bir araya getirilmesiyle elde edilirken işaret dillerinde işaretler parmak alfabesindeki sembollerin bir araya getirilmesiyle elde edilmez; kelimeyi karşılayan tek bir sembol (işaret) vardır. Bazı harfler A harfinde olduğu gibi Türkçedeki karşılığının gösterilmesi şeklinde veya J harfinde olduğu gibi harfin çiziminin gerçekleşmesi şeklinde icra edilir (Şekil 5).

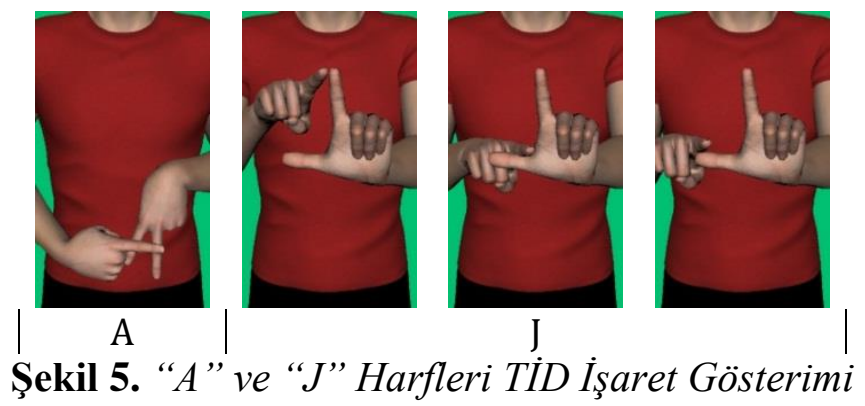

Parmak alfabesi harf tabanlıdır (Bayrak, 2009). Türkçedeki her harfin TİD’de bir karşılığı vardır. İşaretin yeterli olmadığ1 veya özel isimlerin ifadesinde parmak alfabesi kullanılmaktadır (Yasan, 2015). Amerikan, Alman ve Fransız İşaret Dilleri parmak alfabesinde tek el kullanılırken (Taşçı, 2016); TiD parmak alfabesinde C, I, L, O, P, U, V dışındaki harflerde çift el kullanılmaktadır (MEB, 2015). Bunun yanında, parmak alfabesinin görünümü bölgelere göre farklılık gösterebilmektedir (Dikyuva vd., 2015).

TID alfabesinde tek elle yapılan işaretlerde sağ elin kullanıldı̆̆ 1 , iki elle yapılan işaretlerde ise sol elin zemin sağ elin ise aktif el olarak kullanıldığı görülmektedir. TIDD parmak alfabesi göğsün ön bölgesinde yapılır. Parmak alfabesi, işaret karşılığı olmayan kelimeleri ifade etmede, diğer işaretlerle birleşerek yeni işaret türetiminde ve bunun yanında aşağıdaki durumlarda kullanılmaktadır (Göksel \& Taşçı, 2016; Bayrak, 2009);

- Özel isimlerde,

- Yabancı dillerden alınan kelimelerde,

- Bilimsel terimlerde,

- Kisaltmalarda, 
- Eklerde,

- Eş anlamlı işaretlerde.

Her ne kadar özel isimler için parmak alfabesinin kullanıldığı söylense de dikkat çekici bir özelliğine göre özel isimler işaretlenebilmekte yani parmak alfabesi yerine işareti tercih edilebilmektedir. Örneğin Samsun şehri parmak alfabesiyle ifade edilmemekte onun yerine Samsun adında sigara olmasından ötürü SİGARA işaretiyle gösterimi yapılmaktadır (Şekil 6).

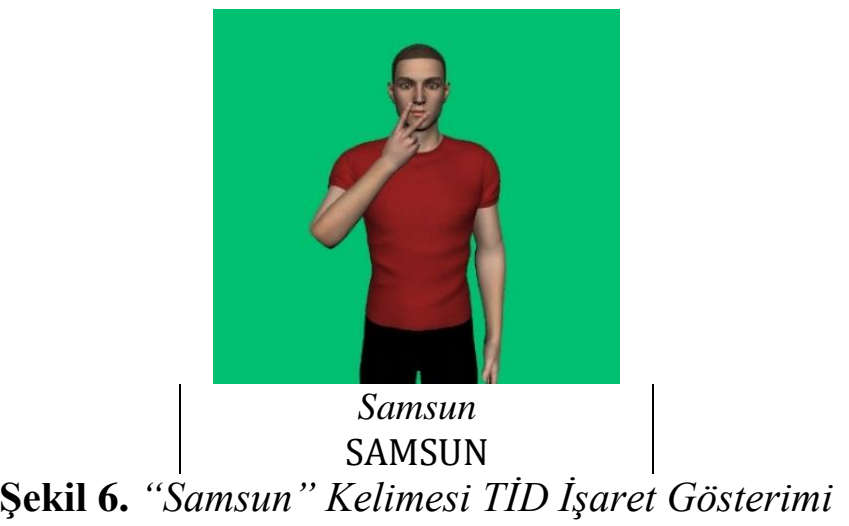

\subsubsection{Ağızla Söyleme (Dudak Okuma)}

Ağızlama, dudak hareketleri şeklinde de isimlendirilen ağızla söyleme, işareti yapılan kelimenin konuşma dilindeki karşılığının ağızla söylenmesidir. Ağızla söyleme, işaretle eş zamanlı olarak yapılır (Göksel \& Taşçı, 2016). İsimlerin ifadesinde fillere oranla daha çok ağızla söylemenin olduğu ortaya konulmuştur (Özkul, 2016).

\subsubsection{Jest ve Mimikler}

TiD, ișitemeyen bireylerin kullanımına daha uygun olan görsel ve jestsel bir dildir (Dikyuva vd., 2015). Bu özelliğinden ötürü işaret dillerinde ve TiD'de jest ve mimikler sıklıkla görülmektedir. El, kol ve baş ile yapılan hareket anlamındaki jest ve buna ek olarak herhangi bir duygu veya düşünceyi anlatan mimiklerin görsel bir dil olan TíD'in temelini oluşturdukları söylenebilir. Her ne kadar mimiklerin işareti desteklemek gibi özellikleri bulunsa da bazı ifadelerde yalnızca mimikler yeterli olabilir. Örneğin; soru ifadesi olan mimikle SAAT işareti yapıldığında Saat kaç? anlamı çıkar (Şekil 7). Kısacası, ele ait olan ve olmayan unsurlar olan jest ve mimiklerin işaretlerde tekil veya birlikte kullanılmasıyla işaret dilleri meydana gelmektedir.

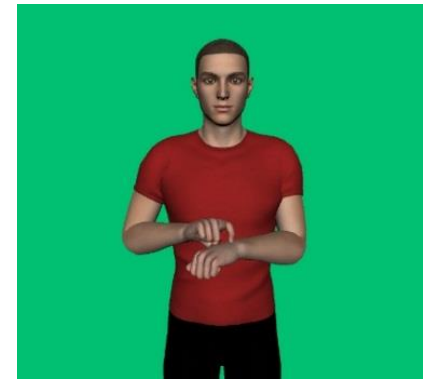

Saat SAAT

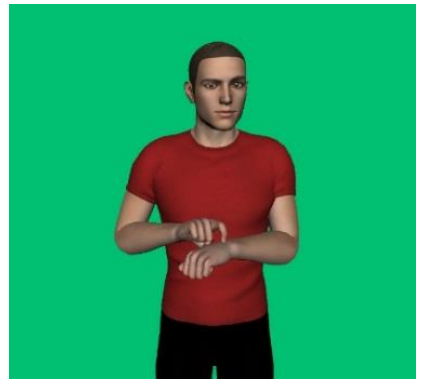

Saat kaç?

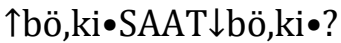

Şekil 7. "Saat" kelimesi ve "Saat kaç?" Cümlesi TiD İşaret Gösterimi 


\subsection{TİD Dil Bilgisi}

Her dilin olduğu gibi işaret dillerinin de kendine özgü birtakım kuralları vardır. İşlemler TIDD dil bilgisi kuralları çerçevesinde icra edilmektedir. Ayrıca işaret dillerini konuşma dillerindeki kelimelerin işaret karşılıklarının ardı ardına yapılmasıyla oluşturulan bir dil olarak görmek doğru değildir (Kubuş vd., 2016). Cümle oluşturmada kelimelerin işaret karşılıklarının birleşimi TỉD dil bilgisi kurallarına göre gerçekleştirilmektedir.

Konuşma dillerinde görülen sözcük düzeyindeki bölgesel farklılık TİD'de benzer şekildedir; dil bilgisel farklılık görülmemekte ve bu durum farklı bölgelerdeki işitme engellilerin TİD ile iletişimini engellememektedir (Dikyuva vd., 2015).

TİD'de işaret, ağızla söyleme ile jest, mimiklerin senkron şekilde gerçekleşmesi gerekmektedir. Çünkü bazı kelimelerin anlamı sadece işaretin yapılmasıyla verilemez; tamamlayıcı unsur olan dudak ve farklı anlam verilebilmesine imkân sağlayan mimiklerin bir arada kullanılması şarttır.

İşaretlerin gerçekleştirilmesinde sürekli aynı el tercih edilmelidir. Aksi takdirde karşıdaki kişi elleri takip ederken işareti ve dudak hareketini kaçırabilir. Tek elle yapılan işaretlerde işaretin hangi elle yapılacağı belirlenmeli ve devamlı olarak o el kullanılmalıdır. Bununla birlikte çift elle yapılan işaretlerde bir el zemin diğeri ise hareketi yapacak aktif el olarak tespit edilmeli ve eller değiştirilmemelidir.

Bu bölümde kelime türetiminden söz dizimine kadar TíD’e ait dil birçok dil bilgisel konular örneklerle ele alınmıştır. Türkçe ile TİD her ne kadar ayrı iki dil olsalar da sözdizimi gibi birtakım noktalarda benzerlikler bulunmaktadır. Bu iki dil arasındaki farklılıkların çoğullaştırma, olumsuzlaştırma ve zaman gibi dilbilimsel özelliklerde bulunduğu görülmektedir.

\subsubsection{Isşaret Türetme}

Yasan'a (2014) göre TİD işaret türetiminde iki farklı yöntem kullanılmaktadır; algısal özellikten faydalanma ve ses benzeşmesi. Algısal özellikte kelimenin algısal imajından faydalanılır: PERİBACASI (Şekil 8). Ses benzeşmesinde ise iki kelimenin birçok ortak harfe sahip olmalarından veya okunuş benzerliğinden faydalanılır: BACAK ve BACANAK (Şekil 9).

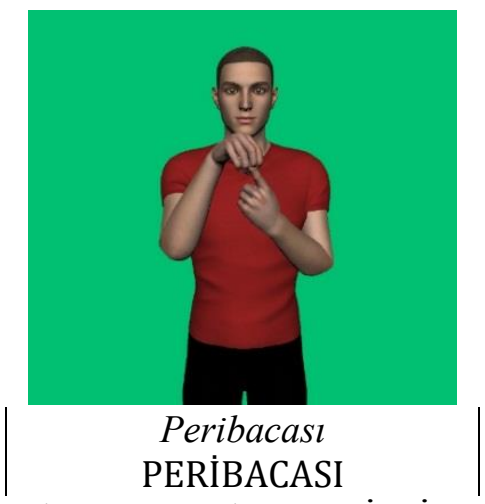

Şekil 8. "Peribacası” Kelimesi TID İşaret Gösterimi 


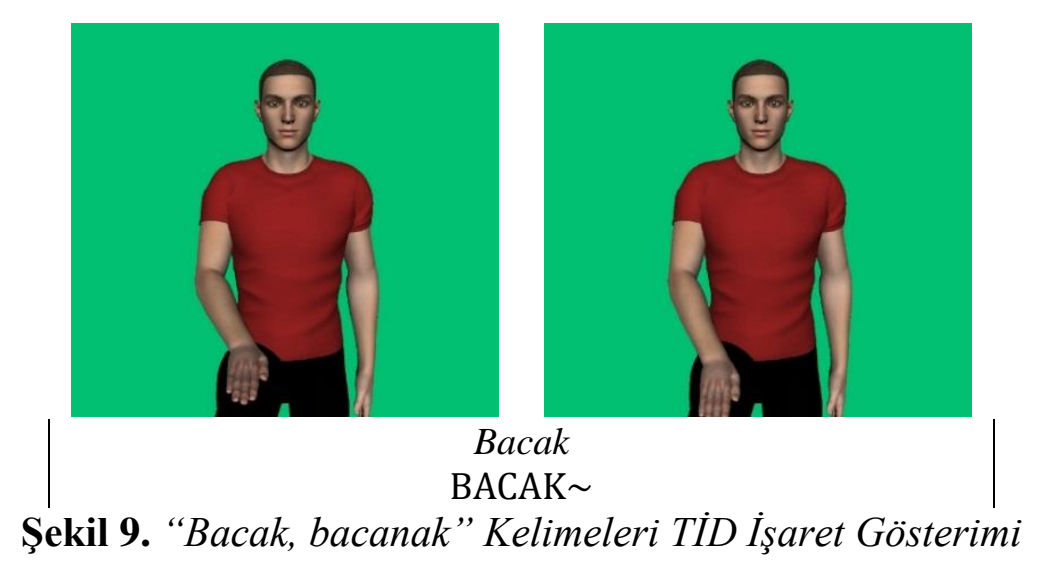

İşaret üretimi konusunda oldukça esnek olan TíD'de harfler ve işaretler çeşitli şekillerde değişime veya birleşime uğrayarak yeni işaretler üretilebilmektedir. Alfabedeki harflerle ve harf birleşimleriyle işaret türetimi yapılabilir. Örneğin; parmak alfabesinde kullanılan harfin farklı şekillerde kullanımıyla yeni anlama sahip işaret meydana gelir; $L \rightarrow$ LAZIM ve $L \rightarrow$ LiSE. Bunun yanında bir işaretin sağına veya soluna parmak alfabesi eklenerek de yeni işaret oluşturulabilmektedir; Jandarma $\rightarrow \mathrm{J}^{\wedge}$ ASKER. Özetle, harf ve işaretlerle işaret türetmede aşağıdaki formlar kullanılmaktadır (Göksel \& Taşçı, 2016; Taşçı, 2016; Boğaziçi Üniversitesi, 2015);

- Tek harfle; L, LAZIM (Şekil 10).

- Birden çok harfin birleşimiyle; Cocacola $\rightarrow \mathrm{C}^{\wedge} \mathrm{C}$.

- İşaretin soluna tek harf almasiyla; Ceket $\rightarrow \mathrm{C}^{\wedge} \mathrm{GiY}$ (Şekil 11).

- İşaretin soluna çok harf almasiyla; Alarm $\rightarrow \mathrm{A}^{\wedge} \mathrm{L}^{\wedge} \mathrm{S}$ ES.

- İşaretin sağına tek harf almasıyla; Psikoloji $\rightarrow \mathrm{BASS}{ }^{\wedge} \mathrm{P}$.

- İşaretin sağına çok harf almasıyla; Bankacl $\rightarrow$ BANKA^ $\mathrm{C}^{\wedge} \mathrm{I}$.

- İki işaretin soluna harf almasıyla; Kablosuz a $\breve{g} \rightarrow \mathrm{W}^{\wedge} \operatorname{SINYAL}^{\wedge} \mathrm{AL}$.

- İki işaretin ortasına harf almasıyla; Psikolojisi bozuk $\rightarrow \mathrm{BAŞ} \wedge{ }^{\wedge} \mathrm{P}^{\wedge} \mathrm{BOZUKLUK}$.
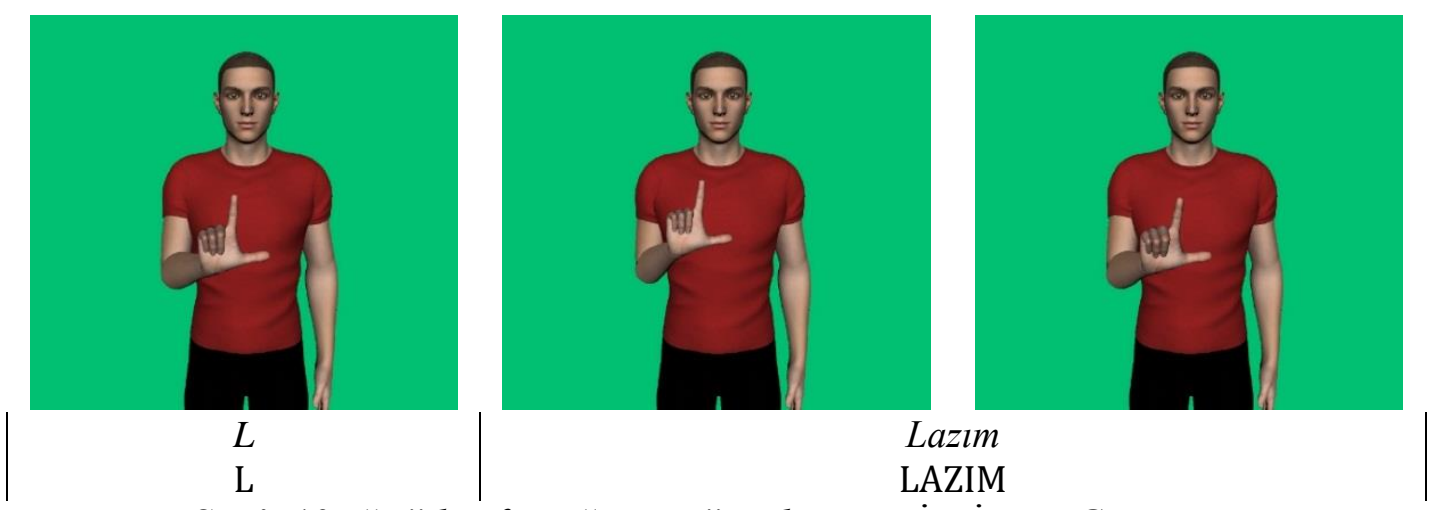

Şekil 10. "L" harfi ve "Lazım” Kelimesi TiD İşaret Gösterimi 

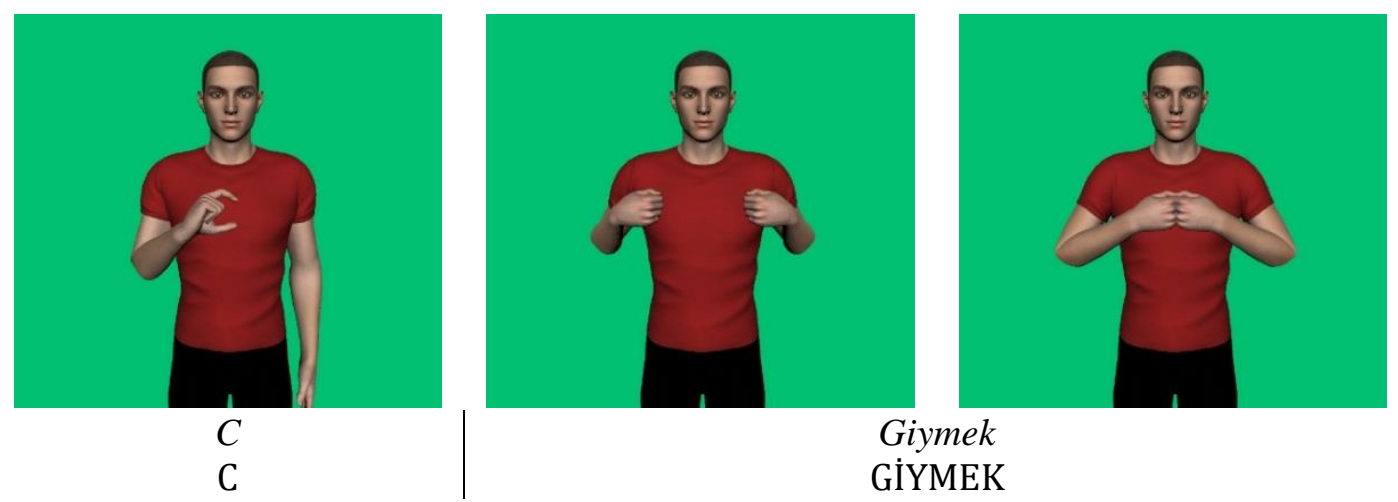

Şekil 11. “Ceket” Işsareti (C^GIYMEK)

Yeni bir işaret türetmenin bir diğer yolu da işaret birleşimidir. TíD'de birleşik işaret oluşturmanın birçok yolu vardır. Örneğin anlambilimsel ve sözdizimsel yaklaşım (Dikyuva vd., 2015);

1. Anlambilimsel yaklaşım: Birleşiği oluşturan işaretlerin anlamlarını esas alır.

1.1. Içe dönük birleşikler: Birleşiğin anlamsal başı ve üst terim olan işaret, birleşiğin içinde yer almaktadır; Abiye $\rightarrow \mathrm{KIZ}^{\wedge} \mathrm{KIYAFET}$ (Şekil 12).

1.2. Dışa dönük birleşikler: Birleşiği oluşturan işaretler kendi anlamlarından uzaklaşarak yeni işaret türetmektedirler; Inatç $\mathrm{l} \rightarrow \mathrm{KAFA}{ }^{\wedge}$ SERT.

1.3. Koşaçsı birleşikler: Birleşiği oluşturan işaretlerden biri esas işarete anlamsal olarak daha yakın bulunmamakta ve birleşiği oluşturan işaretlerde bir üst terim bulunmamaktadır; Okuryazar $\rightarrow$ OKUMA^YAZMA.

2. Sözdizimsel yaklaşım: Birleşiği oluşturan işaretlerin dizilimlerini esas alır.

2.1. Sağ başlı birleşikler: TỉD'de en sık görülen ve birleşiğin başının sağda olduğu türdür; Ayaz $\rightarrow$ HIZLI^SOĞUK (Şekil 13).

2.2. Sol başlı birleşikler: TİD’de yaygın şekilde görülen bu türde birleşiğin baş konumu soldadir; Lezzetli $\rightarrow \mathrm{TAD}^{\wedge} \mathrm{I}$ IYI.

2.3. Çift başlı birleşikler: Baş durumundaki işaretin birleşikte hem sol hem de sağda görülmesidir; Hakl $\rightarrow \mathrm{HAK}^{\wedge}$ DOĞRU, DOĞRU^HAK.

2.4. Eş başlı birleşikler: Koşaçsı birleşiklere benzeyen bu türde birleşiği oluşturan işaretlerde baş durumu yoktur; her biri esas işarete anlamsal olarak eşit mesafededir; Ebeveyn $\rightarrow \mathrm{ANNE}^{\wedge} \mathrm{BABA}$.
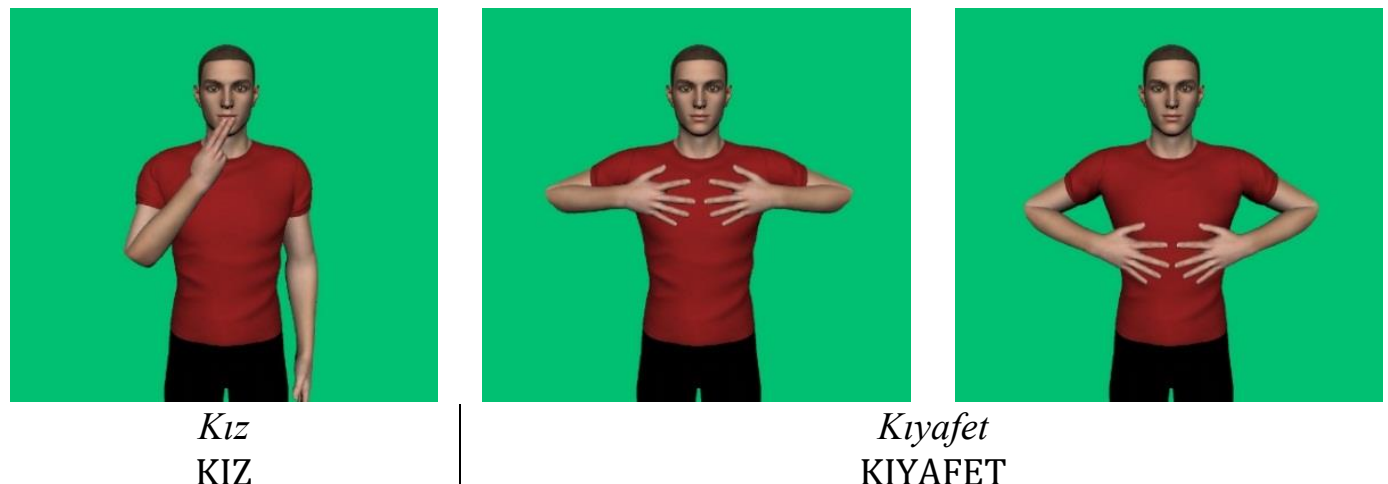

KIYAFET

Şekil 12. Işsaret Birleşimiyle Oluşan İşaretler: “Abiye” Işsareti (KIZ^KIYAFET) 

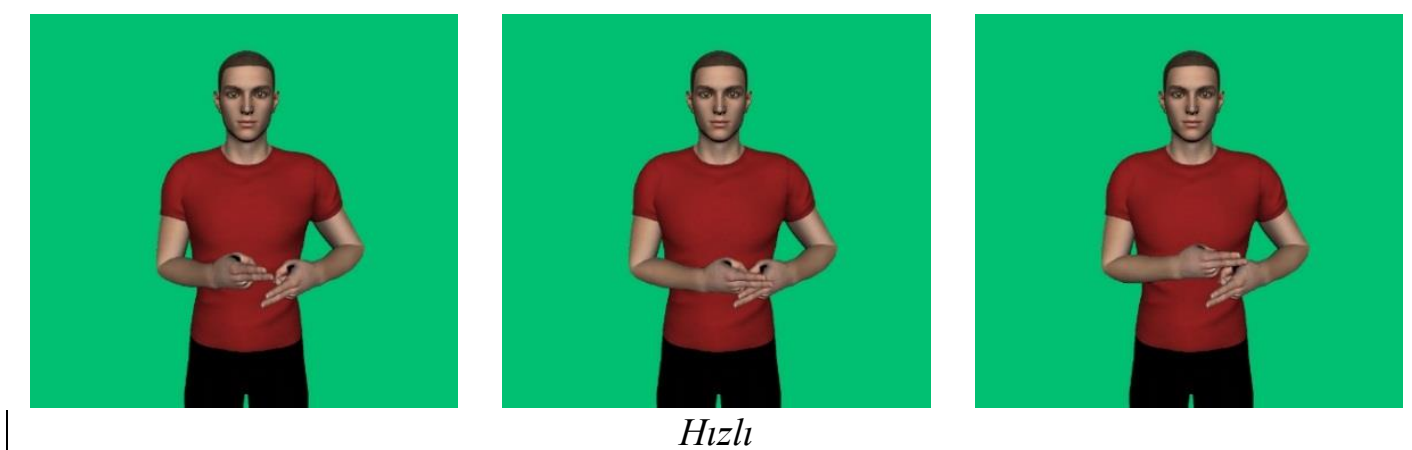

Hizlı

HIZLI

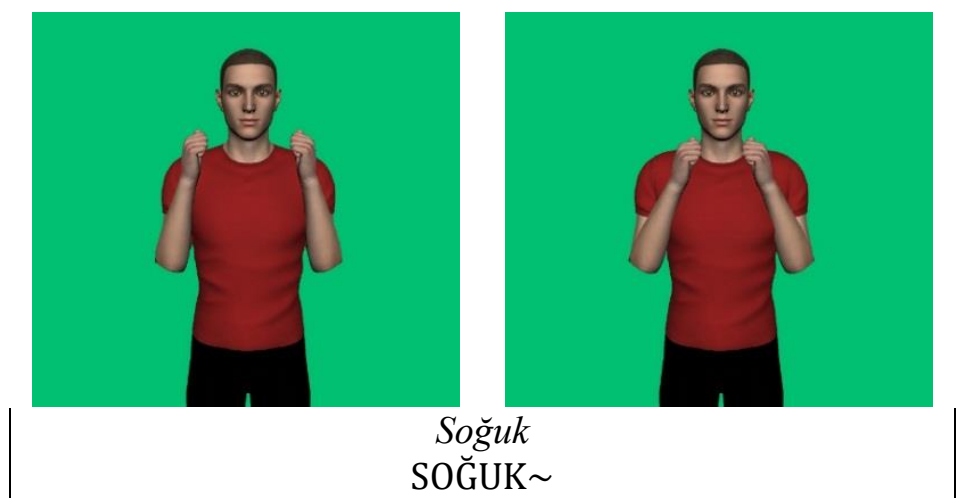

Şekil 13. İşaret Birleşimiyle Oluşan İşaretler: “Ayaz” İşareti (HIZLI^SOĞUK)

TID'de yineleme, işaretin tekraren yapılmasını ifade eder. Bazı işaretlerin bu tekrarlı kullanımı neticesinde yeni anlama sahip işaret üretilir; Çevirmek $\rightarrow$ ÇEVIRMEK, Çeviri $\rightarrow$ ÇEVIRMEK . Bu örnekteki fiilden isim üretimine ters bir örnek olarak tekrarlı kullanım neticesinde isimden fiil üretimi ise şöyle örneklendirilebilir; Kötü $\rightarrow$ KÖTÜ, Kötülemek $\rightarrow$ KÖTÜ (Şekil 14). Ek olarak tek elle yapılan işaretin çift elle yapılmasıyla da kelime türetimi yapılabilir; tek elle Çanta $\rightarrow$ ÇANTA, çift elle Çanta $\rightarrow$ PAZAR (Dikyuva vd., 2015).
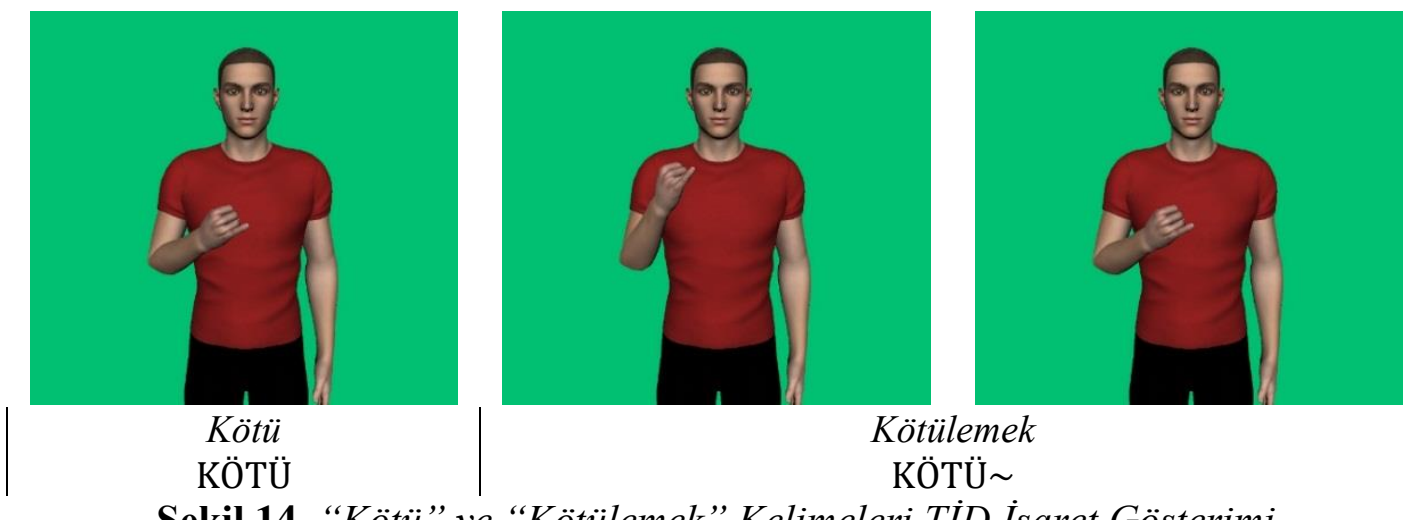

Kötülemek KÖTÜ

Şekil 14. "Kötü" ve "Kötülemek" Kelimeleri TiD İşaret Gösterimi

TiD'de diğer bir işaret üretim yolu da ödünçlemelerdir. Ödünçleme, bir dilde bulunan kelime işaretinin diğer bir dilde kullanılmasıdır. TID ile Türkçe ve diğer işaret dilleri arasında ödünçlemeler meydana gelmektedir. Özellikle yer isimlerinin işareti olarak o bölgedeki işaret ödünçlenerek kullanılmaktadır; BERLIN Alman İşaret Dili’nden alınmıştır (Göksel \& Taşçı, 
2016). Bunun yanında iki kelime arasındaki ses benzerliği sebebiyle de benzeyen kelime için ödünçlenen kelimeye ait işaretin kullanıldığı görülmektedir; İspanya ve Isparta (Şekil 15).

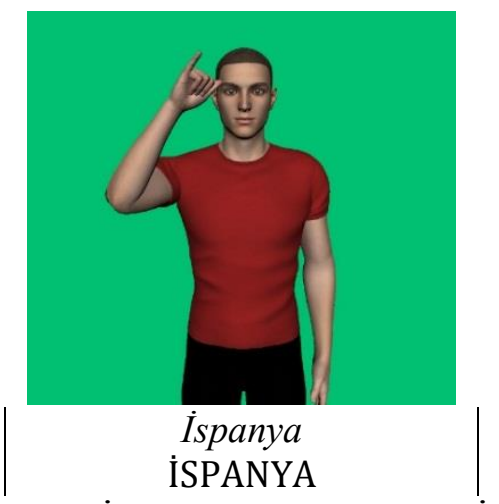

Şekil 15. “Isparta” ve "İspanya” Kelimeleri TíD Işsaret Gösterimi

\subsubsection{Eş İşaretli İşaretler}

Yazılışları aynı olmasına karşın anlamları farklı olan kelimelere Türkçede eş sesli veya sesteş kelimeler denir; yüz kelimesinin sayı olarak 100 ve fiil olarak yüz şeklinde kullanılması gibi (Demir, 2006). TİD açısından eş işaretli, işaretleri aynı olduğu halde farklı anlamlara sahip kelimelerin işaretleri şeklinde tanımlanabilir. TID'de her eş işaretli kelimenin Türkçede de eş sesli olacağını söylemek doğru olmaz. Örneğin İÇIN ve İÇİNDE işaretleri eş işaretli olmasına karşın Türkçede eşsesli değildir (Şekil 16).

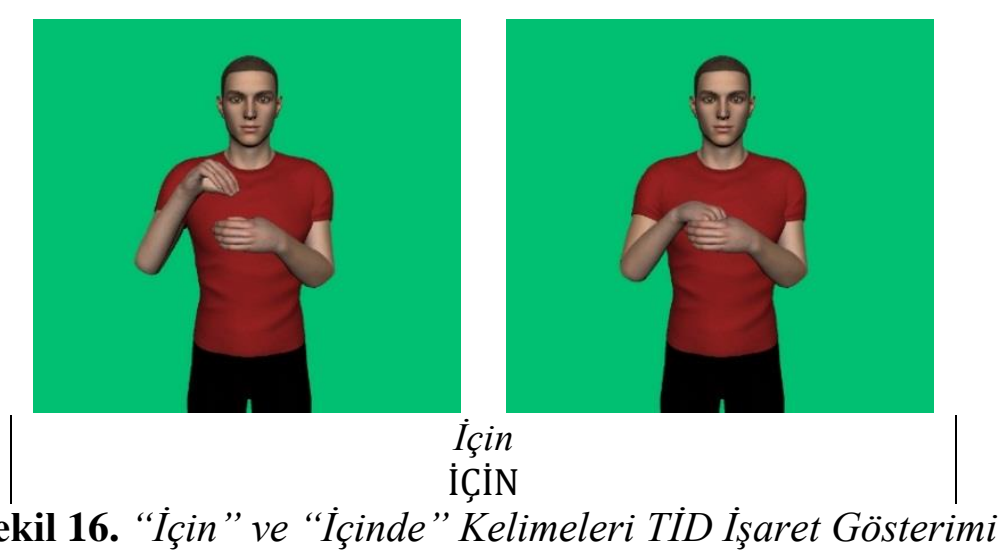

Türkçedeki kelimelerin yazılışlarının aynı olması eş seslilik, TID'de işaretlerin aynı olması ise eş işaretlilik olarak tanımlanabilir. Türkçede aralarında ses benzeşmesi veya anlam yakınlığı bulunan bazı kelimeler TID'de eş işaretli olarak görülebilmektedir: AĞUSTOS, GRİ ve GRAM (Şekil 17), İYİ ve GÜZEL (Şekil 18), TURUNCU, PORTAKAL ve ANTALYA (Şekil 19). Bunun yanında ağızla söyleme, eş işaretli işaretlerin ayırımında kullanılan bir unsurdur (Göksel \& Taşçı, 2016; Oral, 2016). 

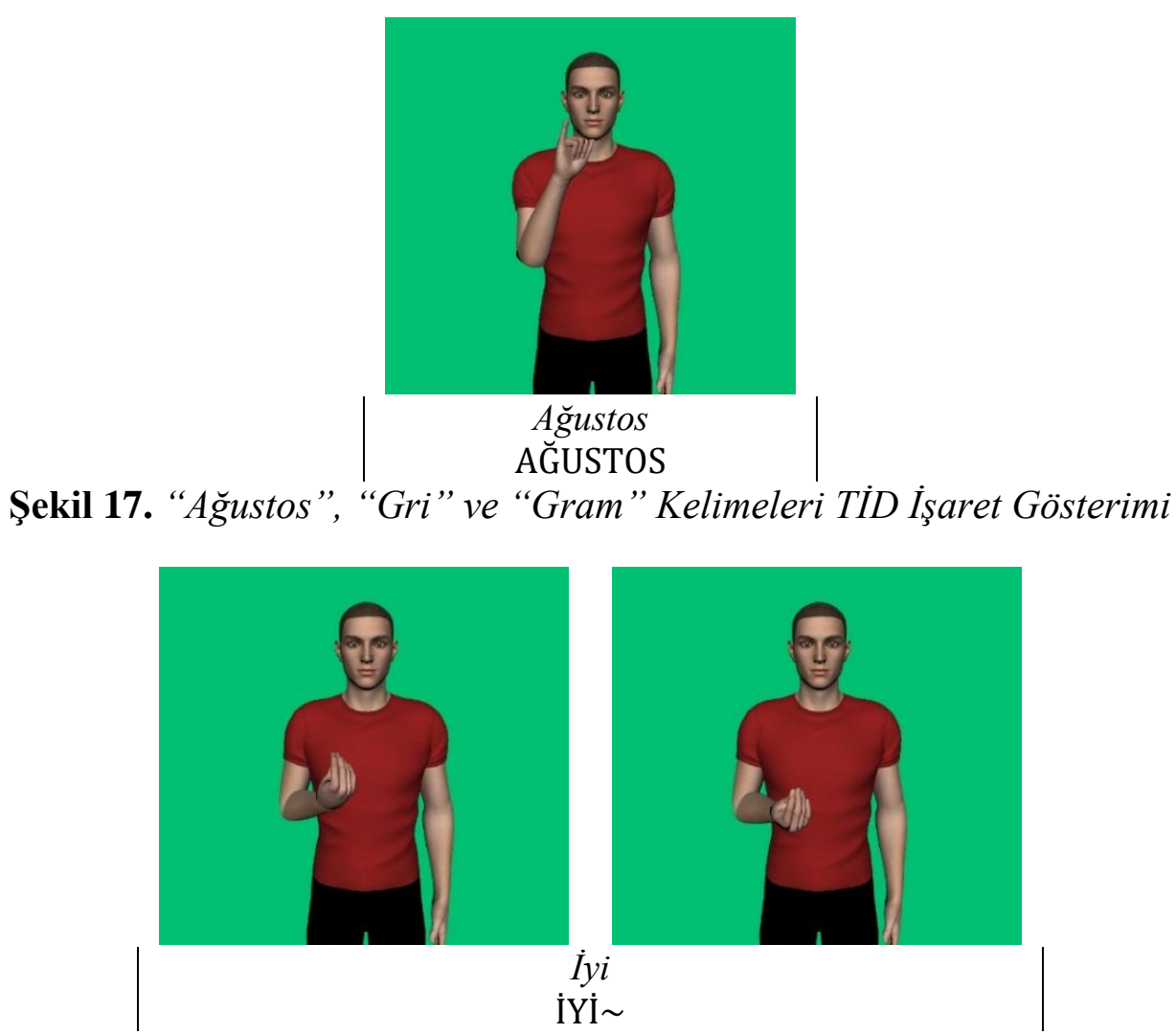

Şekil 18. "İyi” ve "Güzel” Kelimeleri TiD İşaret Gösterimi

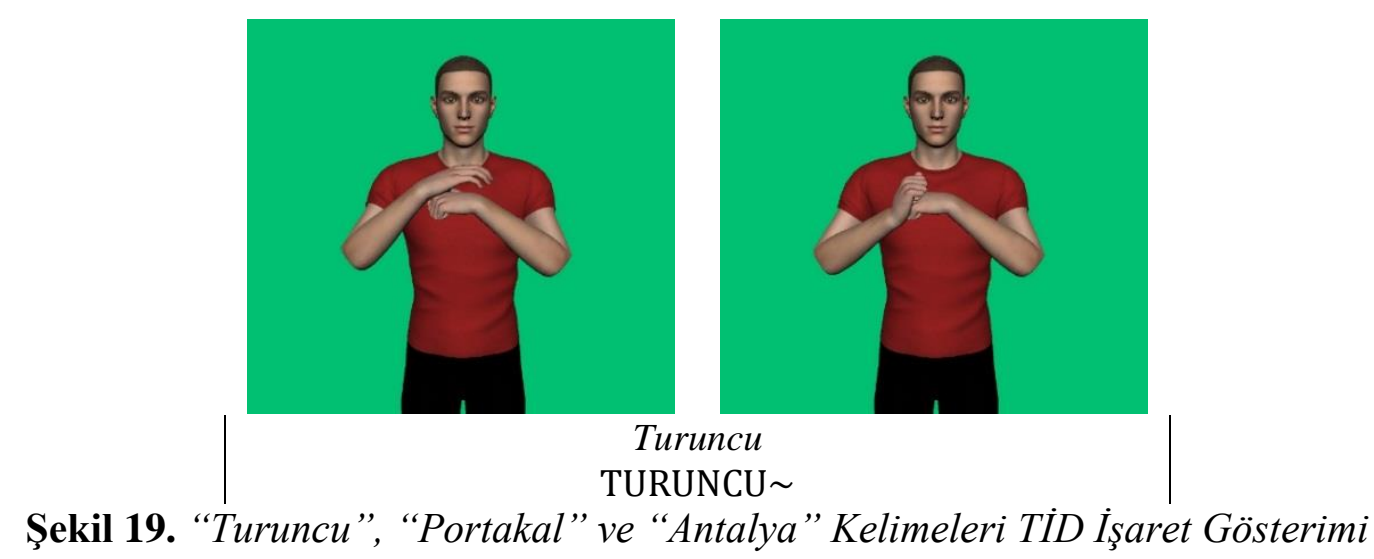

\subsubsection{Eş Anlamlı İșaretler}

Bir kelimeyi farklı sözcüklerle karşılayan kelimelere Türkçede eş anlamlı veya anlamdaş kelimeler denir; yüz, surat ve çehre (Demir, 2006). TiD'de ise eş anlamlı işaretler, bir kelimenin farklı işaretlerle gösterimiyle oluşur; kırmızı (İstanbul, Ankara) (Şekil 20). Genellikle, bölgelere göre farklılıklar gösteren işaretler eş anlamlı işaretler olarak nitelenmektedir (Oral, 2016); cumartesi (İstanbul, Ankara) (Dikyuva vd., 2015). 


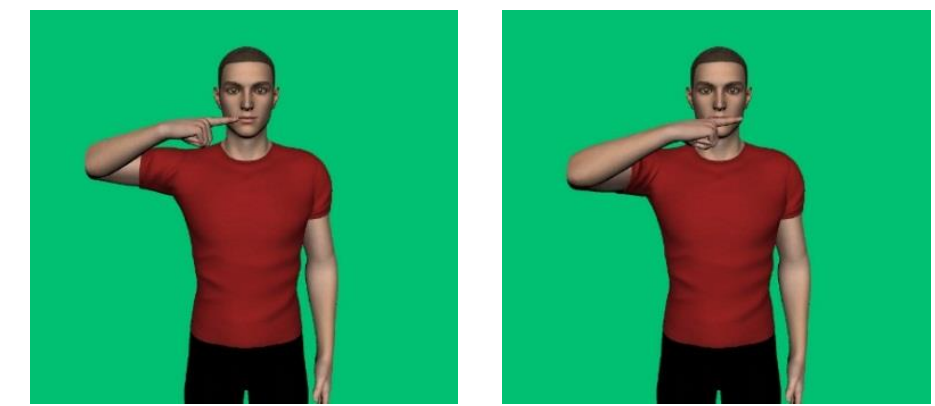

Kırmızı

KIRMIZI

"Kirmizı" (Ankara).

Şekil 20. "Kırmızı" Kelimesi TíD İşaret Gösterimi

\subsubsection{Zıt Anlamlı İșaretler}

Türkçede birbirinin karşıtı kavramları ifade eden sözcüklere zıt anlamlı kelimeler denir; iyi ve kötü (Demir, 2006). Kelime ile olumsuzluk eki almış hali karşıtlık anlamı taşıyor gibi gözükse de karşıt anlamlı değillerdir. Örneğin gitmemek fiili gitmek fiilinin karşıtı değildir; olumsuzudur. DEĞIL bileşeni için de aynı durum geçerlidir; BEYAZ+DEĞİ beyazın karşıtı değildir. Türkçedeki zıt anlamlı kelimeleri karşılayan işaretler, TíD'de zıt anlamlı işaretler olarak isimlendirilir; büyük ve küçük (Şekil 21).

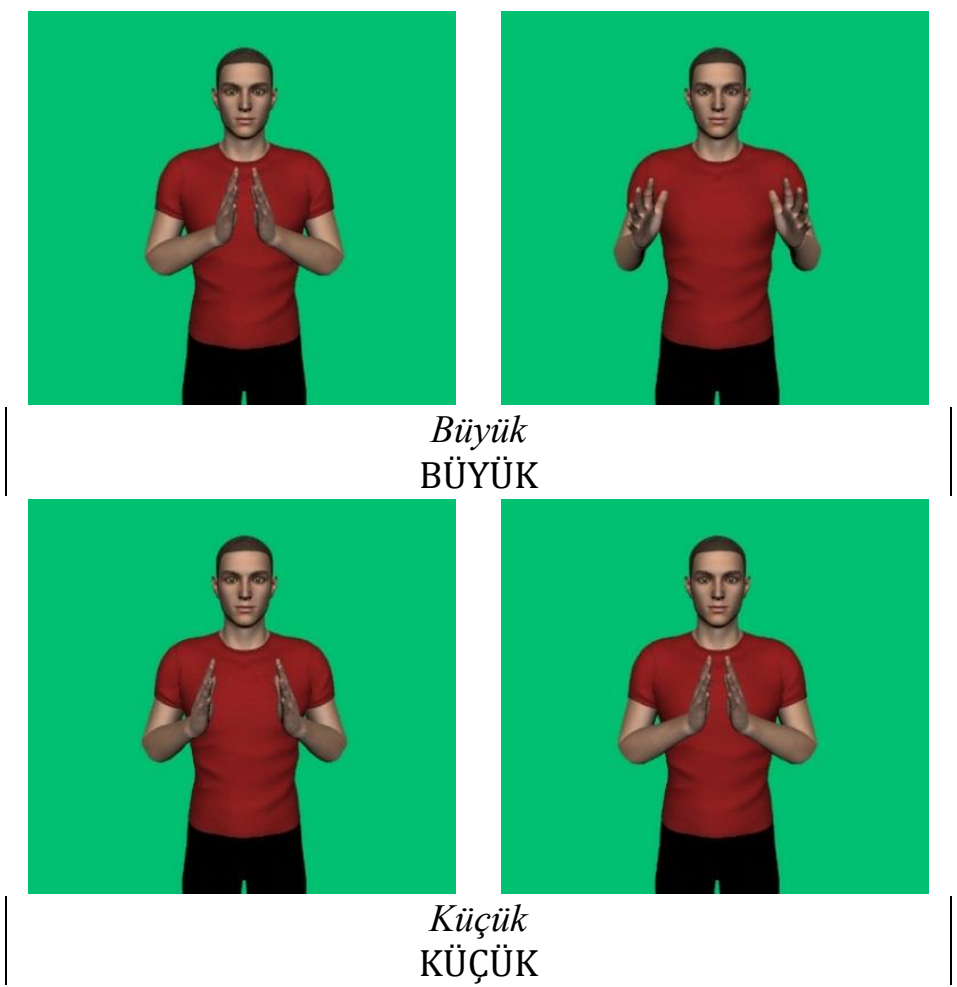

Şekil 21. "Büyük” ve "Küçük” Kelimeleri TiD İşaret Gösterimi 


\subsubsection{Birleşik İşaretler}

TiD'de birden fazla işaretin birleșimiyle oluşan işaretlere birleşik işaret denir. Örneğin Türkçedeki hastane (hasta+hane) kelimesi TID'de HASTA ve YER işaretlerinin birleşimiyle elde edilmektedir (Şekil 22). Buna karşın Türkçedeki ay çekirdeği kelimesi Tỉ'de tek bir işaretle gösterilmektedir.
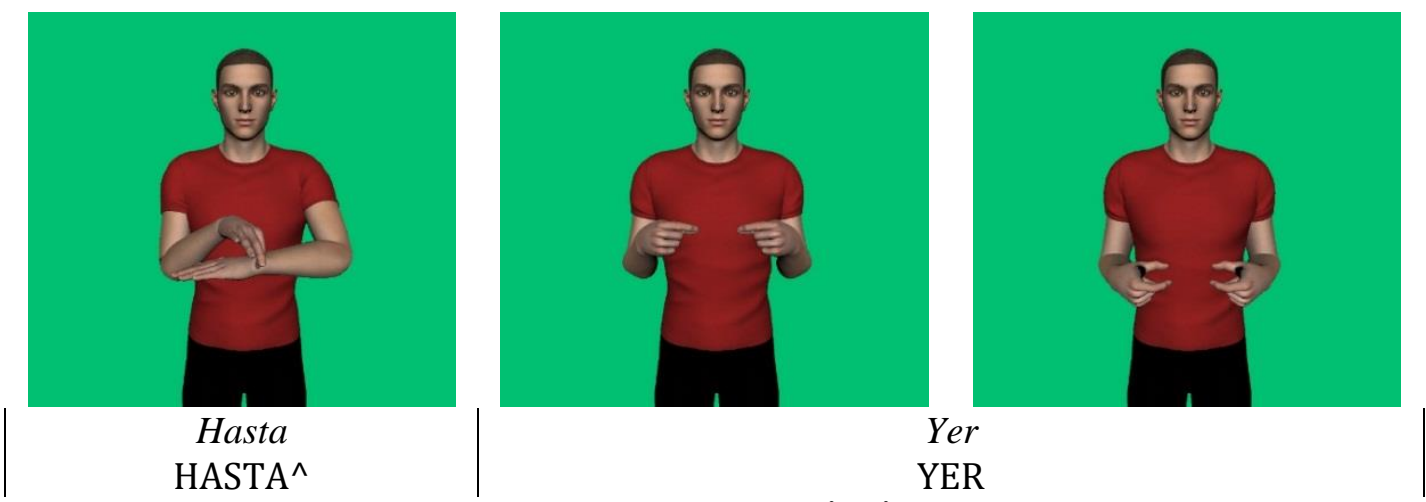

Şekil 22. "Hastane” Kelimesi TID İ̧saret Gösterimi

\subsubsection{Eklerin Kullanımı}

Türkçede yeni anlama sahip kelime üretimi yapım ekleriyle, kelimelerin cümle içinde yer almasının sağlanması ise çekim ekleriyle gerçekleştirilir. Kök/gövdelere ek/ekler getirmek şeklindeki Türkçenin bu eklemeli yapısı TiD'de görüldüğü durumlar olsa da eklerin kullanımında genellikle eş zamanlılık ilkesi görülür. TỉD'de eş zamanlılık yalnızca eklerde değil işaretlerde de bulunmaktadir.

Zaman eklerinin fiilde yer almadığı ve zaman ifadesinin önce, sonra, tamam ve bitti kelimeleriyle verildiği görülmektedir; gittim kelimesi GITTMEK+BEN, ÖNCE+GITMEK+BEN veya di el dışı işaretiyle, gidiyorum kelimesi GITTMEK+BEN, ŞİMDİ+GİTMEK+BEN veya yor el dış1 işaretiyle, gideceğim kelimesi ise SONRA+GITMEK+BEN şeklinde ifade edilebilmektedir. gittim, gidiyorum veya gideceğim kelimelerinde farklı dudak hareketleri olduğundan veya farklı el dışı işaretler kullanıldığından önce, şimdi veya sonra gibi zaman ifadeleri söylenmese dahi anlaşlabilir. Ayrıca, TİD'de zaman bildiren işaretlerin gösterim alanında farklılıklar bulunmaktadır. Zamansal olarak önce ifadesi vücudun omuz hizasından arkaya doğru işaretlenmekte iken sonra ifadesi vücudun ön bölgesinde gerçekleştiği görülmektedir; dün ve yarin.

Kişi zamirleri fiilde ek olarak değil ayrıca kelime işareti olarak yer almaktadır (örn: BEN); gittim kelimesi GITMEK+BEN (Şekil 23), BEN+GITMEK veya BEN+GITMEK+BEN şeklinde kullanılmasına rağmen bu üç kullanımın da işitme engelliler tarafından anlaşılır olduğu söylenebilir. BIZ, SIZ ve ONLAR çoğul kişi adlarına ait işaretler bulunsa da bunların yerine tekil halleri olan BEN, SEN ve 0 sıklıkla kullanılmaktadır. 


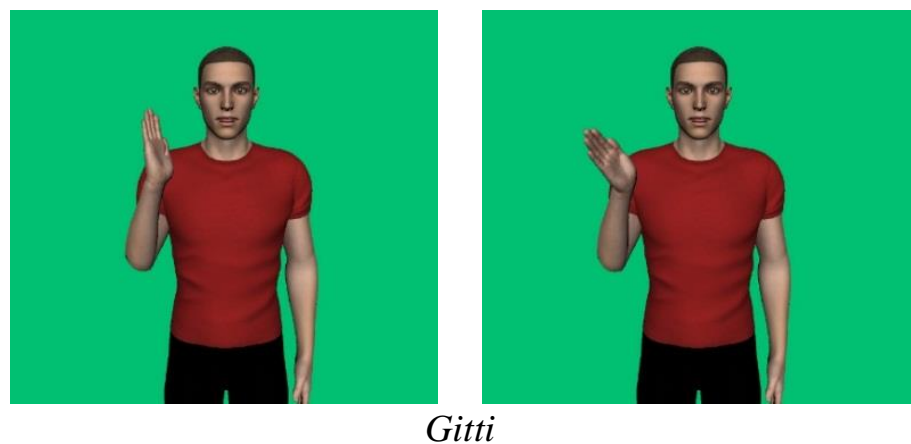

$\uparrow$ di॰GİTMEK $\sim \downarrow$ di $\bullet$

Şekil 23. "Gittim” Kelimesi TiD İşaret Gösterimi

Hal eki kullanımı yoktur; eve kelimesi EV şeklinde çevrilir (Zeshan, 2002). Çoğul ekinde işaret yinelenerek ismin çoğul hali oluşturulabilir; Evler $\rightarrow \mathrm{EV} \sim$ (Şekil 24). Fakat TİD'de tekrarlanarak isimlerin çoğul hallerinin elde edilmesiyle ilgili şunu söylemek gerekir; işaret aynı yerde tekrarlanmaz, yatay düzlemde sağdan sola doğru tekrarlanır. Ayrıca işaretin çoğul hali, İŞARET+ÇOK birleşimiyle veya ISŞARET+C sınıflandırıcısıyla sağlanabilmektedir; Elmalar $\rightarrow$ ELMA+ÇOK, ELMA+C (sınıflandırıcı). İşaretin yavaş şekilde yapılmasıyla çok ifadesi verilmektedir; Çok zengin $\rightarrow$ ZENGIN (yavaşça).

Olumsuzluk ifadesi ise İŞARET+DEĞİL şeklinde gerçekleştirilmektedir; gelmemek kelimesi TID'e GELMEK+DEĞİL şeklinde çevrilmektedir (Şekil 25). Buna karşın bazı kelimeler ile olumsuz hallerinin işaretleri farklılık göstermektedir; istemek ile istememek ve yeter ile yetmez. Olumsuz ifadelerde genellikle el dişı işaretlerden olan baş yukarda ve kaş yükseltme, işarete eş zamanlı olarak eşlik etmekte ve sadece ilgili işarette görülmektedirler.

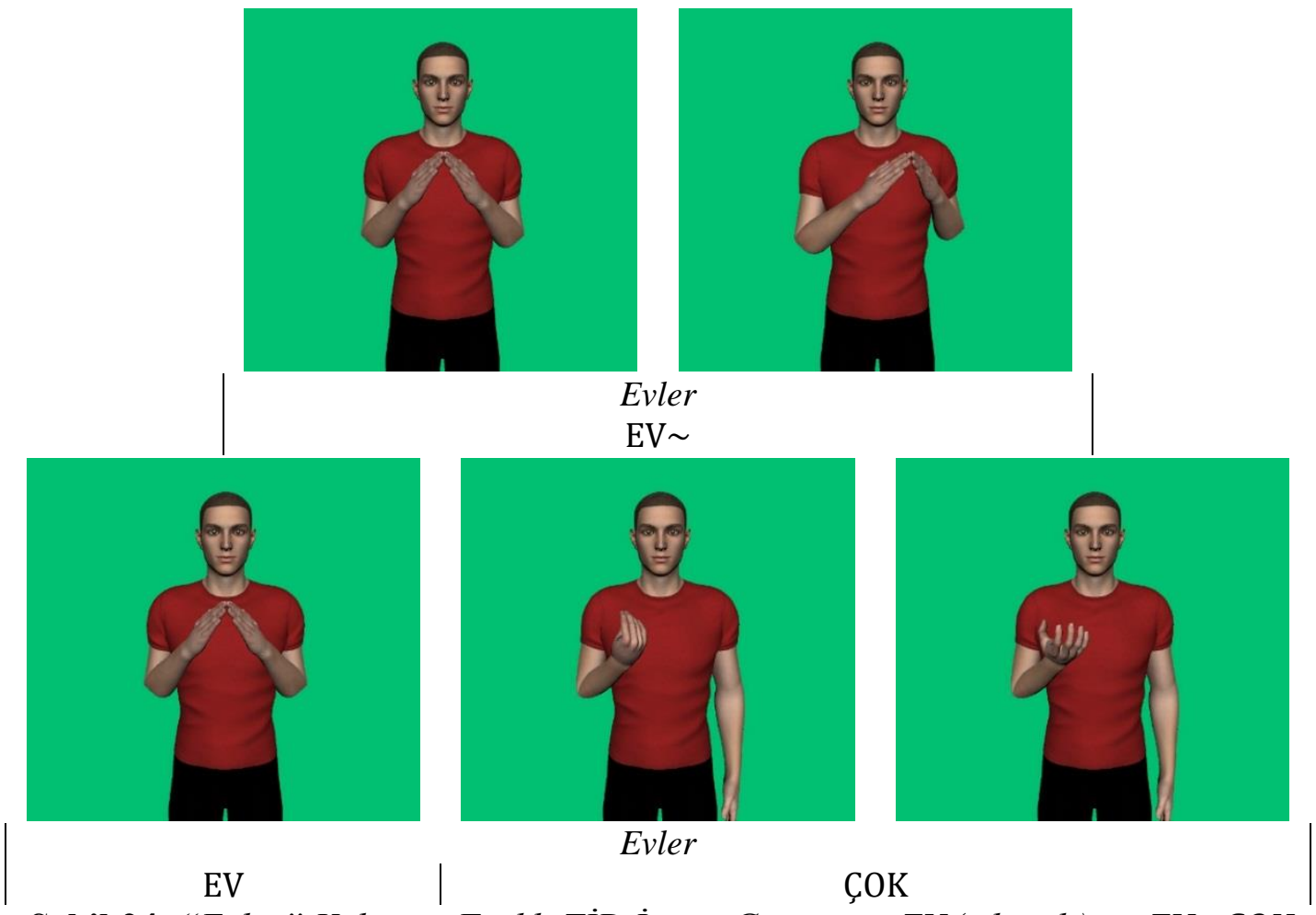

Şekil 24. "Evler” Kelimesi Farklı TID İşaret Gösterimi EV(tekrarlı) ve EV+ÇOK 


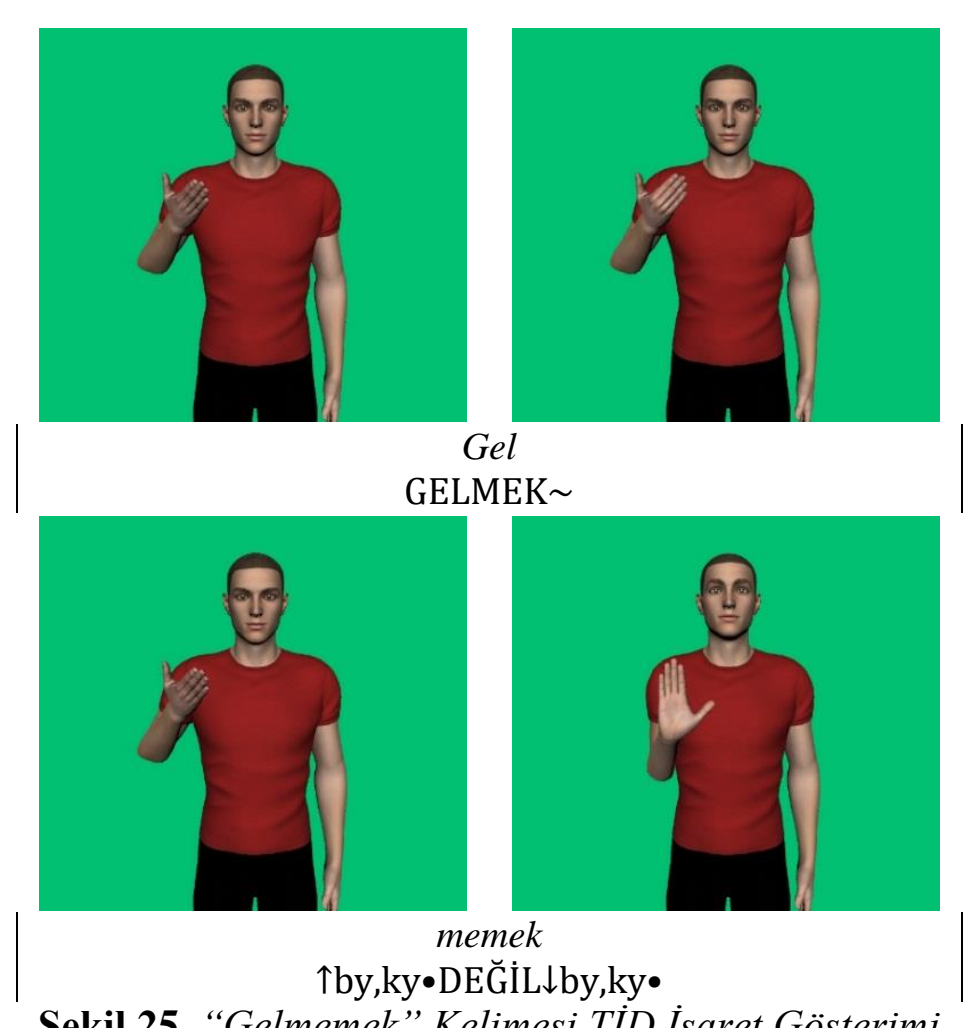

Şekil 25. "Gelmemek” Kelimesi TiD İşaret Gösterimi

İyelik ekiyle ilgili iki işaret kullanılabilse de iyelik ifadesinde yoğun olarak kullanılan ve daha kapsayıcı şekilde bulunan el şekli tercih edilmektedir. Benim kelimesi, Şekil 26'daki el şeklinin kişinin kendisini gösterecek şekilde işaretlenmesiyle elde edilir (Şekil 26).

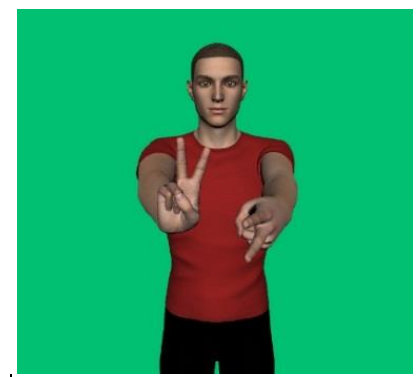

El șekli

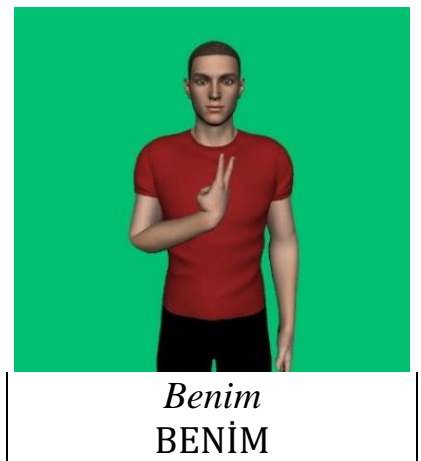

BENIM

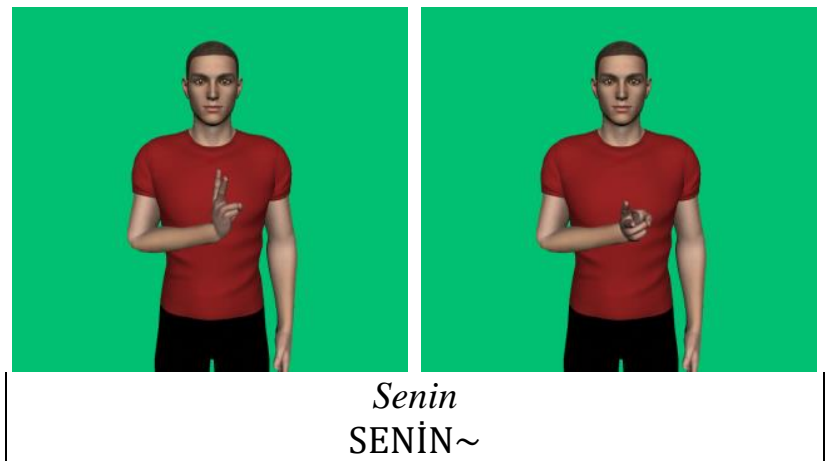

SENIN

Şekil 26. İyelik Ekinde Kullanılan El Şekli, "Benim” ve "Senin” Kelimeleri TiD İşaret Gösterimi

İzin kipi kullanımında eylem işaretinden sonra SERBEST işareti ile kodlama yapılır; Gidebilirsin $\rightarrow$ GITMEK+SERBEST (Şekil 27). 
Karaca \& Bayır (2018)

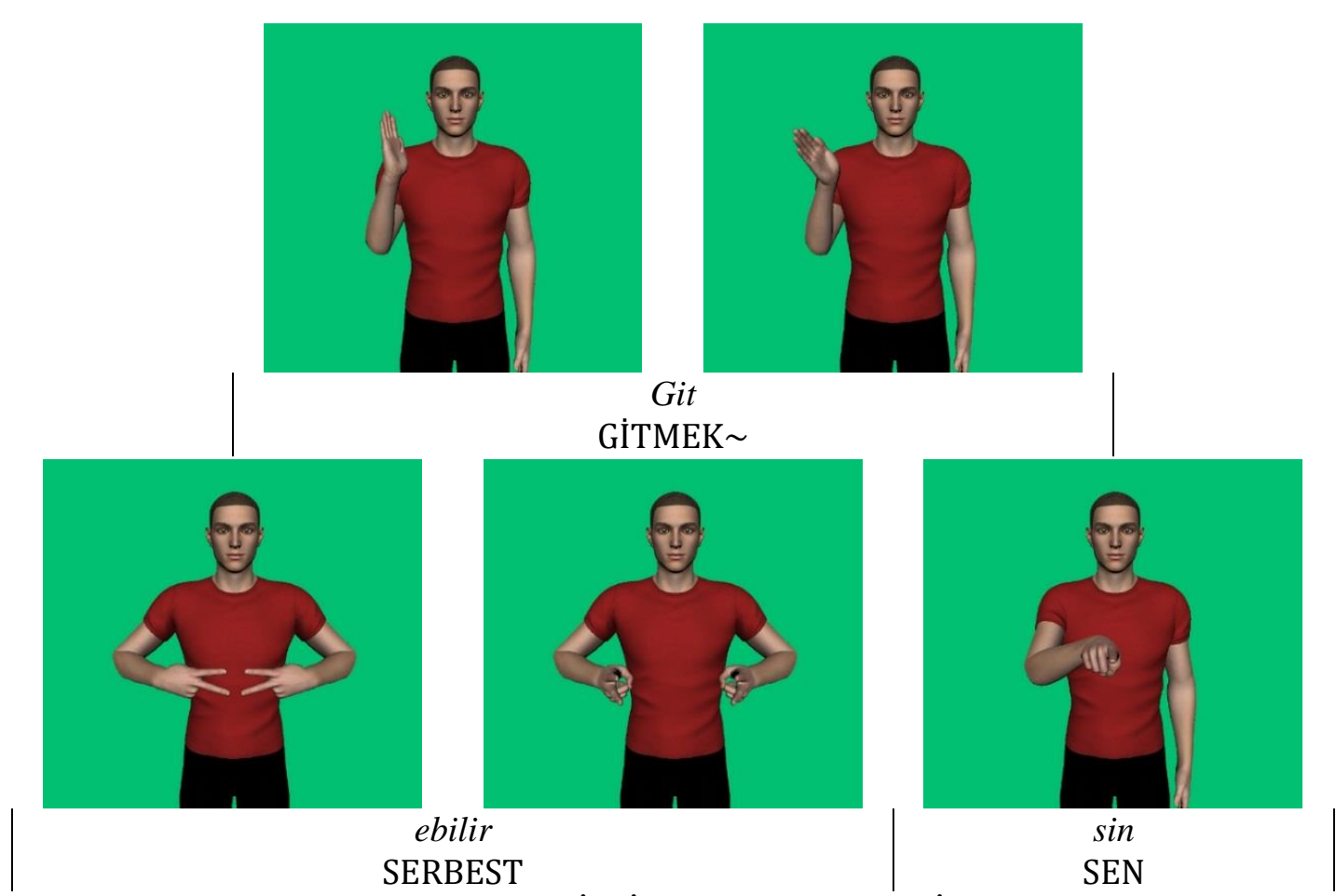

Şekil 27. “Gidebilirsin” Kelimesi TID İşaret Gösterimi (GITMEK+SERBEST+SEN)

Zorunluluk kipinde eylem bildiren işaretten sonra MECBUR işareti ile kodlama yapılır; Gitmen gerekiyor $\rightarrow$ GITMEK+MEBCUR+SEN. Gereklilik kipinde işaretten sonra LAZIM işareti ile gösterim gerçekleşmektedir; Gitmelisin $\rightarrow$ GITTMEK+LAZIM+SEN (Şekil 28) (Dikyuva vd., 2015; Oral, 2016).

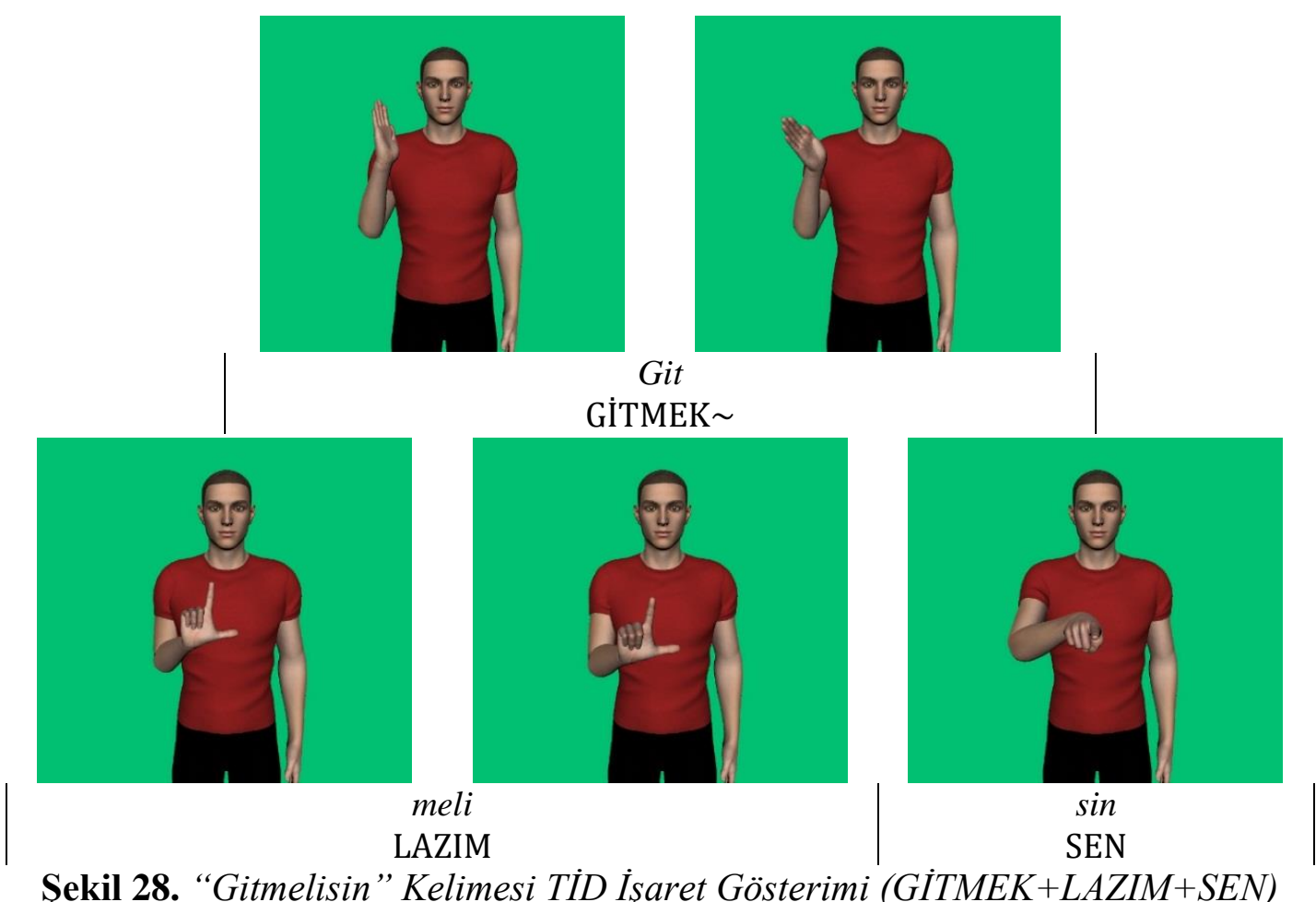


Konu yapım ekleri bakımından incelendiğinde ise farklı bir durum ortaya çıkmaktadır. Türkçede yapım eki almış bir kelimenin yeni hali TỉD'de farklı bir işaretle veya ek almak suretiyle ifade edilebilir. Örneğin; $e v$ kelimesi - li yapım eki alarak evli kelimesini türetmektedir ve bu iki kelimenin işaretleri birbirinden farklıdır (Şekil 29). Bunun yanında aynı ek (-li) bir yer adına geldiğinde kelime $\mathrm{L}^{\wedge} \mathrm{I}$ harf işaretlerinin birleşimiyle gösterimi gerçekleştirilir. Örneğin; Tokatll kelimesinin işareti TOKAT${ }^{\wedge} \mathrm{L}^{\wedge} \mathrm{I}$ birleşimiyle elde edilir. Bunun yanında, Türkçede bir işi yapan kişi anlamında $-c l$ yapım eki bulunmaktadır. $-c i,-c l,-c \ddot{u},-c u,-c ̧ \iota,-c ̧ \ddot{u}$ ve $-c ̧ u$ gibi farklı şekilleri bulunsa da Türkçedeki bu ek, TID'de iki şekilde görülür. İlki Bilgisayarcl $\rightarrow$ BİLGISAYAR ${ }^{\wedge} \mathrm{C}^{\wedge} \mathrm{I}$ örneğinde olduğu gibi işarete $\mathrm{C}^{\wedge} \mathrm{I}$ veya $\mathrm{C}^{\wedge} \mathrm{U}$ harflerinin eklenmesiyle elde edilir. İkincisi ise $C$ harfine benzer el şeklinin alın seviyesinden aşağıya doğru inmesi şeklinde de işaretlendiği görülmektedir (Göksel \& Taşçı, 2016).

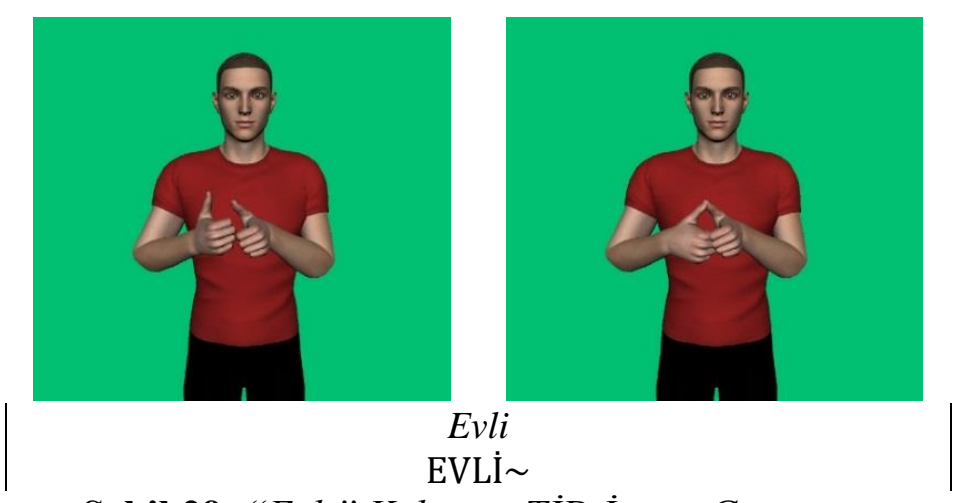

Şekil 29. "Evli" Kelimesi TiD İşaret Gösterimi

\subsubsection{Söz Dizimi}

Söz dizimi, cümleyi oluşturan öğelerin dizilimini ve bu dizilimdeki kuralları ifade eder. Dillerde genellikle Özne+Nesne+Yüklem veya Özne+Yüklem+Nesne dizilimi kullanılmaktadır. TiD'de ise Türkçeye benzer şekilde Özne+Nesne+Yüklem veya bunun farklı bir formu olan Nesne+Yüklem (Özne) dizilişinin sıklıkla kullanıldığı görülmektedir (Oral, 2016). Fakat işaret dillerindeki el dışı işaretler gibi unsurların eş zamanlılık sağlamasıyla öğelerin aynı zamanda işaretlenmesi diziliş kurallarını ortaya koymayı zorlaştıran etkendir.

Ben eve geldim.

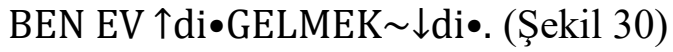

BEN EV $\uparrow$ di $\bullet$ GELMEK $\sim \downarrow$ di $\bullet+B E N$.

$\mathrm{EV} \uparrow$ di $\bullet$ GELMEK $\sim \downarrow$ di $\bullet+B E N$.
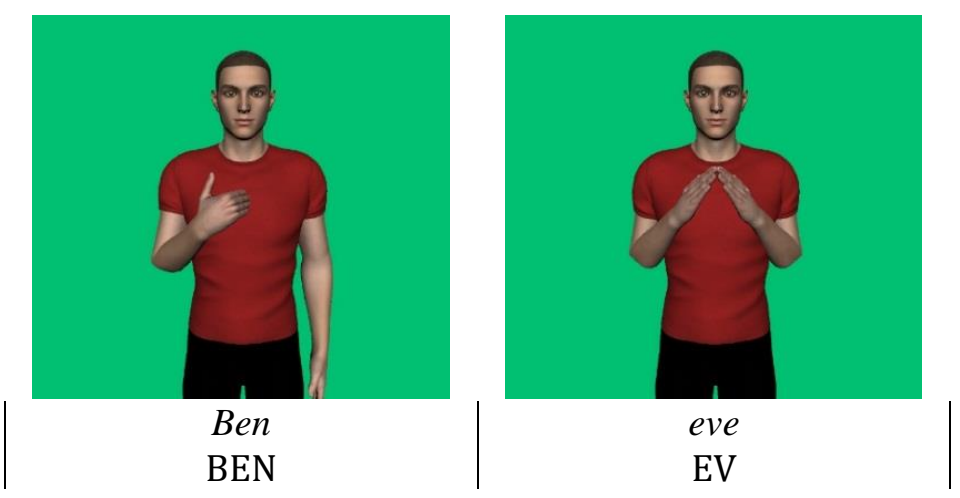
Karaca \& Bayır (2018)

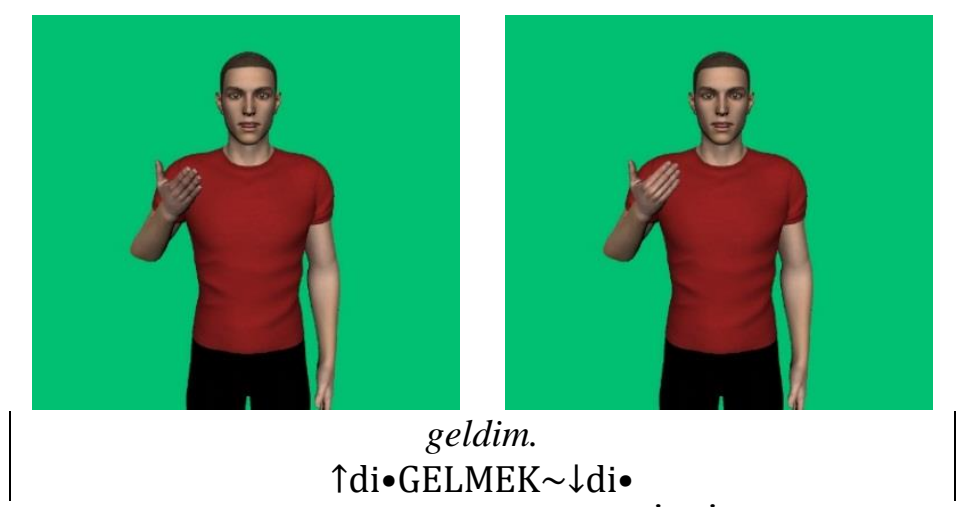

Şekil 30. “Ben eve geldim.” Cümlesi TỉD Işsaret Gösterimi

Dizilimde dil dışı durumlar incelendiğinde TID ile Türkçe arasında benzerlikler görülmüştür (* olan cümleler dil dışı cümle örnekleridir). Aşağıdaki cümledeki dil dişı durumun Türkçe ifadesi Benim hasta anne.' dir ki bu cümle Türkçede bu şekilde ifade edilmez. Örneklerde görüleceği Türkçedeki dil dışı dizilişler genellikle TİD’de de dil dışılığa sebep olmaktadır.

\section{Benim annem hasta.}

BENIM ANNE HASTA. (Şekil 31)

*BENIM HASTA ANNE.
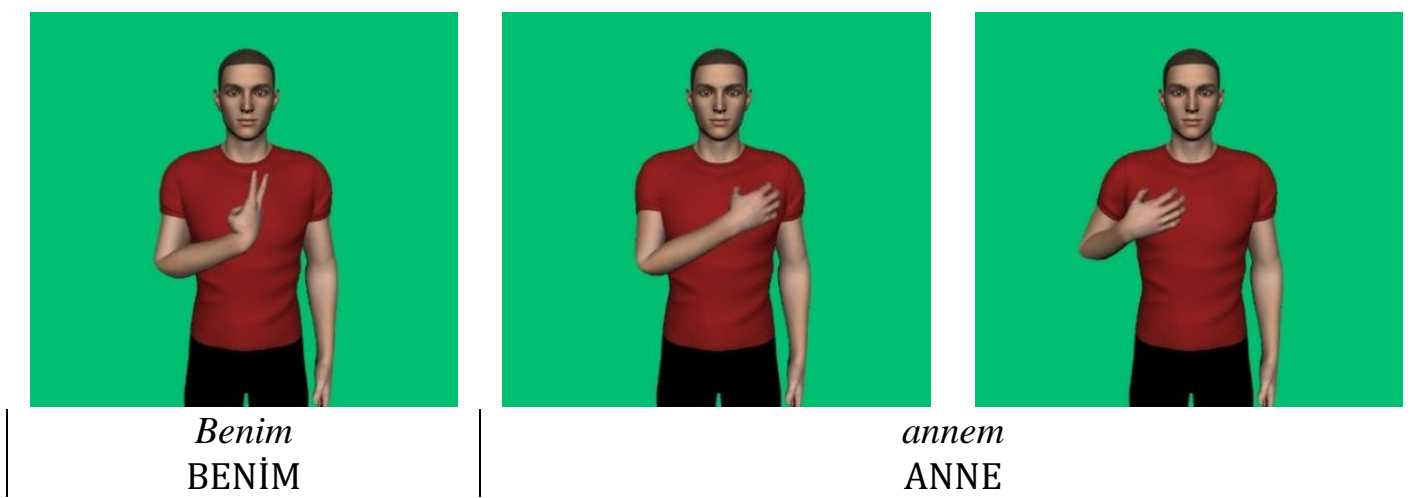

annem

BENIM

ANNE

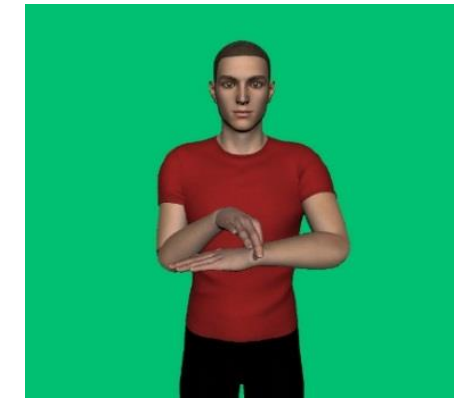

hasta.

HASTA

Şekil 31. “Benim annem hasta.” Cümlesi TID Işaret Gösterimi

$\ddot{U}$ ç yeni kalem aldım.

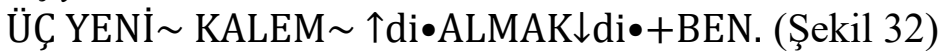

*ÜÇ KALEM YENİ $\uparrow$ di $\bullet A L M A K \downarrow d i \bullet+B E N$.

*YENİ $\sim$ KALEM $\sim$ ÜÇ $\uparrow$ di $\bullet A L M A K \downarrow d i \bullet+B E N$. 


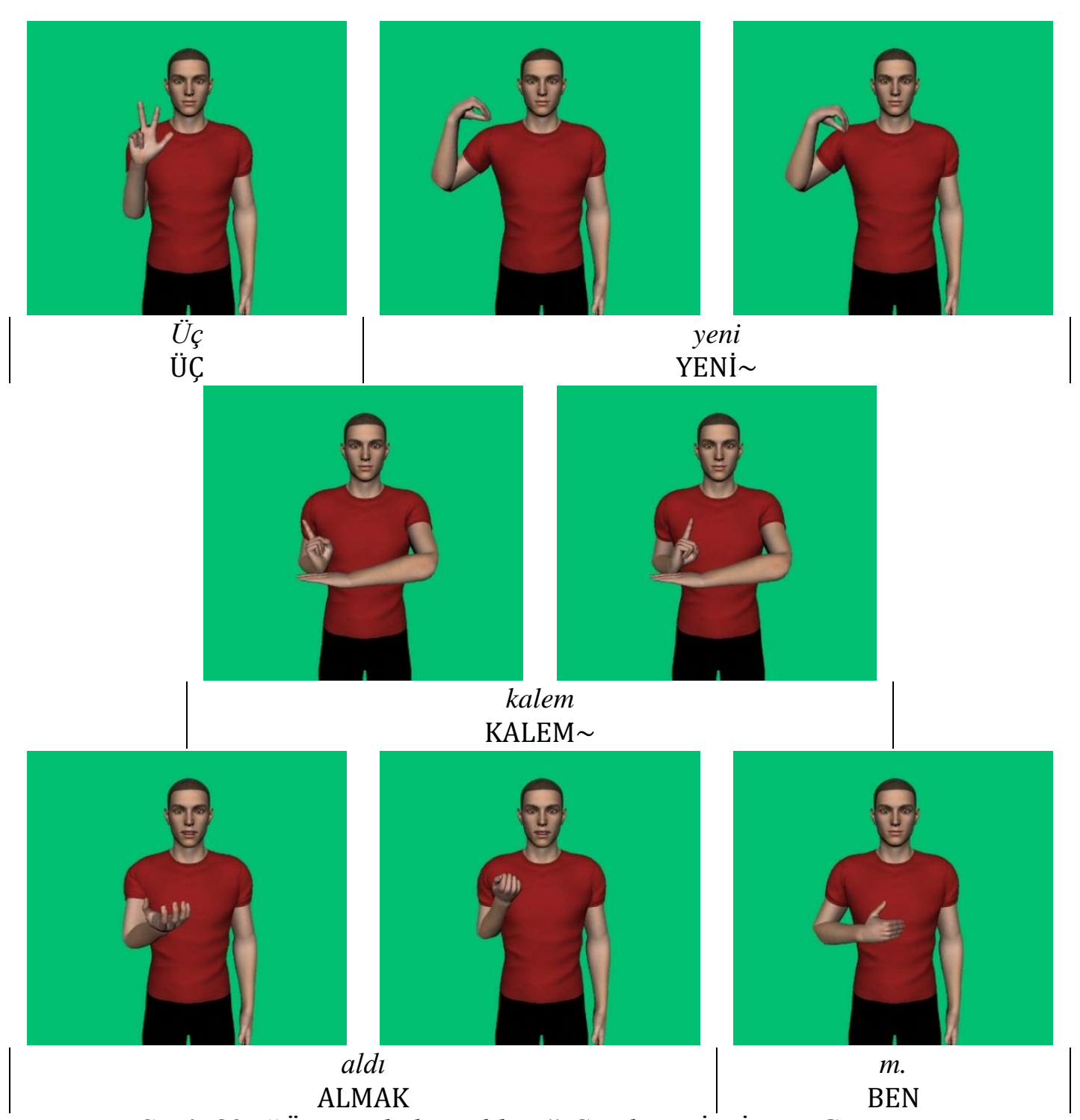

Şekil 32. "Üç yeni kalem aldım." Cümlesi TiD İşaret Gösterimi

\section{Sonuç}

İletişimin sözlü, sözsüz, yazılı ve elektronik olmak üzere türleri bulunmaktadır. İşitme engelliler kendi aralarında çoğunlukla sözsüz iletişim olan işaret dilini kullanırlar. İşaret dili, işitme engellilerin en temel iletişim tekniğidir; el hareketleri, jest, mimikler, tamamlayıcı veya pekiştirici olan ağızla söylemeden oluşur. Konuşma dillerinde olduğu gibi her ülkenin işaret dilinde bulunan işaretler ve dil bilgisi kuralları farklıdır.

Dünyadaki en eski işaret dillerinden TíD ile ilgili özellikle dil bilgisi noktasında sınırlı sayıda çalışma bulunmaktadır. Bu çalışmada TíD iletişim yöntemleri ve dil bilgisi kuralları incelenmiştir. İletişimde kullanılan yöntemler olarak işaretler, parmak alfabesi, ağızla söyleme ve jest-mimikler ele alınmıştır. Dil bilgisi olarak ise işaret türetme, eş işaretli, eş anlamlı, zıt anlamlı ve birleşik işaretlerin yanı sıra TiD'de eklerin kullanımı ve TỉD söz dizimi araştırılmıştır. TíD iletişim yöntemleri ve dil bilgisine ait özellikler özet şeklinde ayrı ayrı sunulmuştur. 
TİD iletişimine ait özellikler şu şekilde özetlenebilir;

- Durağan ve durağan olmayan işaretler vardır.

- İşaretler kelime tabanlıdır (Bayrak, 2009).

- Türkçe kelime ile işareti arasında imgesel bağ kurulması gerekmez.

- İşaretler şeffaf, yarı şeffaf ve şeffaf olmayan şeklinde sınıflandırılmaktadır (Klima \& Bellugi, 1979).

- Türkçe bazı kelimeler tek bir işaretle bazıları ise birden fazla işaretin birleşimiyle meydana gelebilir (Uysal, 2010).

- İşaret, uygulama yerine göre farklı anlamlara gelebilir (Türk, 2015).

- Parmak alfabesindeki bazı harfler gösterilerek veya bazıları ise çizilerek icra edilebilir.

- Parmak alfabesi harf tabanlıdır (Bayrak, 2009).

- TID parmak alfabesinde C, I, L, O, P, U, V dişındakilerde çift el kullanılmaktadır (MEB, 2015).

- Parmak alfabesinin görünümü bölgelere göre farklılık gösterebilmektedir (Dikyuva vd., 2015).

- Parmak alfabesi şu durumlarda kullanılır; özel isimlerde, yabancı dillerden alınan kelimelerde, bilimsel terimlerde, kısaltmalarda, eklerde, eş anlamlı işaretlerde (Göksel \& Taşçı, 2016; Bayrak, 2009).

- Eğer özel ismi karşılayan bir işaret varsa özel isim parmak alfabesiyle değil işaretle gösterimlenir.

- TID'de jest ve mimikler s1klıkla görülmektedir.

- Bir işaretin jest ve mimiklerle kullanımıyla anlam farklılaşabilir (olumsuz, soru gibi).

TİD dil bilgisine ait özellikler şu şekilde özetlenebilir;

- Her dilde olduğu gibi TİD’in de kendine özgü kuralları vardır.

- Konuşma dillerinde var olan bölgesel farklılıklar işaret dillerinde de görülmektedir.

- İşaretlerin yapımında sürekli aynı el kullanılmalıdır.

- İşaret türetmede esnek bir dildir.

- İşaret türetmede cismin algısal özelliğinden veya başka bir kelimeyle olan ses benzeşmesinden faydalanılabilir (Yasan, 2014).

- Harfleri farklı şekil ve kombinasyonlarda kullanarak işaret türetimi yapılabilir (Göksel \& Taşçı, 2016; Taşç1, 2016; Boğaziçi Üniversitesi, 2015).

- Anlambilimsel ve sözdizimsel yaklaşımla işaret türetimi yapmak mümkündür (Dikyuva vd., 2015).

- Yineleme, tek elle yapılan işaretin çift elle yapılmasıyla (Dikyuva vd., 2015) ve başka işaret dillerinden ödünçleme (Göksel \& Taşçı, 2016) ile işaret türetimi yapılabilir.

- Türkçe iki kelime arasındaki ses benzeşmesi veya anlam yakınlığı sebebiyle eş işaretlilik görülmektedir.

- Eş işaretli işaretler vardır. Türkçedeki her eş anlamlı kelime TİD'de de eş işaretli veya TİD'de her eş işaretli işaret Türkçede eş anlamlı olmak durumunda değildir.

- Eş anlamlı işaretler genelde bir kelimeye ait işaretin bölgesel farklılık sebebiyle farklı şekillerde gösterimlenmesiyle ortaya çıkar (Oral, 2016).

- Birleşik işaretler TİD’de işaret türetme yöntemi olarak kullanılmaktadır. 
- Fiildeki zaman ekleri değiş̧ik formlarda, fiille birlikte zamana ait işaretlerle, kişi zamirleri de değişik formlarda, fiille birlikte ve kişi zamirlerine ait işaretlerle kodlanmaktadır.

- Hal eki kullanımı yoktur (Zeshan, 2002).

- Çoğul ekleri işaret tekrarı, IŞ̧ARET+ÇOK birleşimi veya ISŞARET+C sınıflandırıcısı şeklinde kullanılır.

- Fiildeki olumsuzluk ifade İŞARET+DEĞIL birleşimiyle verilir ve by ve ky el dışı işaretleriyle birlikte kullanılır.

- İzin kipi ISŞARET+SERBEST birleşimi ile sağlanır.

- Gereklilik ve zorunluluk ekleri için IŞARET+LAZIM veya ISSARET+MECBUR birleşimi tercih edilir.

- Türkçede bir kelime ile yapım eki almış hali farklı işaretlerle gösterilebilir.

- Bazı yapım eklerinde ise ISŞARET+PARMAK ALFABESİ kullanımı görülür.

- TID'in söz diziminde Türkçeye benzer fakat Türkçeden daha fazla forma sahip olduğu söylenebilir.

- Türkçedeki dil dışı dizilişler genelikle TíD'de de dil dışı durum oluşturur.

- Bildirim cümlesi ile soru cümlesini el dışi işaretler ayırır.

- Evet/hayır ve ne tipli soru cümlelerde kullanılan el dışı işaretler farklılıklar göstermektedir.

- Evet/hayır tipli soru cümlelerinde bö ve ky, ne tipli soru cümlelerinde ise bö ve ki el dışı işaretleri cümlenin tamamında görülmektedir.

\section{Referanslar}

Akalın, Ş. H. (2013). Türk İşaret Dili. Yeni Türkiye Dergisi (Türkçe Özel Saylsl), 55, 1496-1502. Akçamete, G. (1999). Improving question skills for students with hearing impairment, The European Journal of Special Needs Education, 14(2), 171-177.

Bayrak, S. (2009). İşaret dilinin bilgisayarlı yorumlanması. Yüksek Lisans Tezi, Karadeniz Teknik Üniversitesi Fen Bilimleri Enstitüsü, Ankara.

Demir, T. (2006). Türk dilbilgisi. (2. Baskı). Ankara: Kurmay Kitap Yayın ve Dağıtım.

Dikyuva, H., Makaroğlu, B. \& Arık, E. (2015). Türk İ̧saret Dili dilbilgisi kitabı. Ankara: Aile ve Sosyal Politikalar Bakanlığı.

Gökgöz, K. \& Arık, E. (2011). Distributional and syntactic characteristics of nonmanual markers in Turkish Sign Language (Türk İşaret Dili, TID). MIT Working Papers in Linguistics, Proceedings of WAFL VII, 62, 63-78.

Göksel, A. \& Taşçı, S. S. (2016). Türk İşaret Dili’nde ödünçlemeler, Ellerle konuşmak: Türk İşaret Dili araştırmaları. (1. Baskı). Ed. Engin Arık. İstanbul: Koç Üniversitesi Yayınları.

İnternet: Boğaziçi Üniversitesi. (2015). Türk İşaret Dili sözlüğü v1.0, http://www.cmpe.boun.edu.tr/pilab/tidsozlugu.

Kelepir, M. \& Göksel, A. (2016). Türk İşaret Dili’nde aktarılmış anlatımın özellikleri, Ellerle konuşmak: Türk İşaret Dili araştırmaları. (1. Baskı). Ed. Engin Arık. İstanbul: Koç Üniversitesi Yayınları. 
Kubuş, O., İlkbaşaran, D. \& Gilchrist, S. K. Türkiye'de işaret dili planlaması ve Türk İşaret Dili'nin yasal durumu, Ellerle konuşmak: Türk Işaret Dili araştırmaları. (1. Baskı). Ed. Engin Arık. İstanbul: Koç Üniversitesi Yayınları.

Kükey, M. (1975). Uygulamalı örneklerle Türkçenin sözdizimi. Ankara: Kardeş Matbaası.

Makaroğlu, B. (2012). Türk İşaret Dilinde soru: Kaş hareketlerinin dilsel çözümlemesi. Yüksek Lisans Tezi, Ankara Üniversitesi Sosyal Bilimler Enstitüsü, Ankara.

Makaroğlu, B. (2016). Türk İşaret Dili’nde soru tümcelerinin görünümü: Kaş hareketlerinin rolü, Ellerle konuşmak: Türk İşaret Dili araştırmaları. (1. Bask1). Ed. Engin Arık. İstanbul: Koç Üniversitesi Yayınları.

Memiş, A. (2013). Kinect Rgb görüntülerinde ve derinlik haritalarında uzam-zamansal özellikleri kullanarak işaret dili tanıma. Yüksek Lisans Tezi, Yıldız Teknik Üniversitesi Fen Bilimleri Enstitüsü, İstanbul.

MEB (Milli Eğitim Bakanlığı - Özel Eğitim ve Rehberlik Hizmetleri Genel Müdürlüğü) (2015). Türk İşaret Dili Sözlüğü, http://orgm.meb.gov.tr/alt_sayfalar/duyurular/l.pdf .

Oral, A. Z. (2016). Türk İşaret Dili çevirisi. (1. Bask1). Ankara: Siyasal Kitabevi.

Özkul, A. (2016). Türk İşaret Dilinde araç bildiren isim ve fiil çiftlerine birimbilimsel bir bakış, Ellerle konuşmak: Türk İşaret Dili araştırmaları. (1. Baskı). Ed. Engin Arık. İstanbul: Koç Üniversitesi Yayınları.

Taşçı, S. S. (2016). TİD el alfabesinin sözlükleşmesi ve biçimlenişsel yapılandırılması: El değişimi ve benzeşme olguları, Ellerle konuşmak: Türk Işsaret Dili araştırmaları. (1. Bask1). Ed. Engin Arı. İstanbul: Koç Üniversitesi Yayınları.

Tutar, H., Yılmaz, M. K. \& Eroğlu, Ö. (2014). Genel Teknik İletişim. 6. Bask1. Ankara: Seçkin Yayıncilik.

Türk, Y. (2015). Türk-Alman işaret dilleri tercümesi etkinliğinin örneklerle incelenmesi. Yüksek Lisans Tezi, Sakarya Üniversitesi Sosyal Bilimler Enstitüsü, Sakarya.

Uysal, A. (2010). İşitme engellilerde Türkçe öğretimi, sorunlar, öneriler. Yüksek Lisans Tezi, İstanbul Üniversitesi Sosyal Bilimler Enstitüsü, İstanbul.

Yasan, M. C. (2014). Türkçe metni Türk İşaret Diline dönüştürme. Yüksek Lisans Tezi, Başkent Üniversitesi Fen Bilimleri Enstitüsü, Ankara.

Zeshan, U. (2002). Sign Language in Turkey: The story of a hidden language. Turkic Languages, 6(2), 229-274.

Zeshan, U. (2003). Aspects of Türk İsaret Dili (Turkish Sign Language). Sign Language and Linguistics, 6(1), 43-75. 